\title{
Apropiación del territorio y espacialidad en el Islote (Caribe colombiano) ${ }^{*}$
}

\author{
Andrea LeIVA E. \\ Doctorante, École Pratique des Hautes Études \\ leiva.andrea@gmail.com
}

Recibido: 28-09-12

Aceptado: 14-04-13

\section{RESUMEN}

Este artículo explora las formas de apropiación del territorio y las prácticas de espacialidad en el Archipiélago de San Bernardo (Bolívar, Colombia). El objetivo es describir y analizar las formas en que los habitantes del Islote - la isla que concentra la principal población del archipiélago - se apropian, organizan e interactúan con su entorno insular y continental por medio de los contactos con diferentes territorios. Este conjunto de prácticas y relaciones componen lo que aquí denominamos espacio isleño.

Palabras clave: Caribe; Colombia; espacialidad; territorio; movilidad.

\section{Appropriation of territory and spatiality in Islote (Colombian Caribbean)}

\begin{abstract}
This article explores forms of territorial appropriation and spatial practices in the archipelago of San Bernardo (Bolivar, Colombia). Our aim is to describe and analyze the forms in which the Islet's inhabitants -the island where a major part of the population in the archipelago lives- appropriate themselves, organize and interact with their insular and continental environment by means of contacts with the different territories. This set of practices and relations represent what we call islander space (espacio isleño).
\end{abstract}

Key words: Caribbean; Colombia; spatiality; territory; mobility.

\section{Apropriação do território e espacialidade no Islote (Caribe colombiano)}

\begin{abstract}
RESUMO
Este artigo explora as formas de apropriação do território e as práticas de espacialidade no Arquipélago de São Bernardo (Bolívar, Colômbia). O objetivo é descrever e analisar as formas em que os habitantes do Islote - a ilha que concentra a principal população do arquipélago - se apropriam, organizam e interagem com seu entorno insular e continental por meio dos contatos com diferentes territórios. Este conjunto de práticas e relações compõe o que aqui denominamos "espaço insulano".
\end{abstract}

\footnotetext{
* Este artículo parte de la ponencia realizada para el Simposio "Fronteras y flujos en sociedades contemporáneas", 54th International Congress of Americanists, Viena, 15-20 de Julio de 2012. Agradezco a Magda Dziubinska, Juan Camilo Niño Vargas, Alvaro Andrés Santoyo, María Dolores Lois Barrio y Lindomar Albuquerque, así como a los evaluadores anónimos por sus valiosas contribuciones y observaciones.
} 
Palavras-chave: Caribe; Colômbia; espacialidade; território; mobilidade.

\section{REFERENCIA NORMALIZADA}

Leiva E., Andrea (2012) "Apropiación del territorio y espacialidad en el Islote (Caribe colombiano)". Geopolítica(s). Revista de estudios sobre espacio y poder, vol. 3, núm. 2, 293-328.

SUMARIO: Introducción. 1. El archipiélago de San Bernardo: presentación geográfica e histórica. 2. Formas de apropiación territorial del archipiélago. 2.1. El Islote: la capital del archipiélago. 2.2. Tintipán: la apropiación y uso del "monte". 2.3. Múcura: el espacio "salvaje". 2.4. Ceycén: el "banco" de los pescadores. 3. Redes espaciales externas del archipiélago. 3.1. El turismo hacia el archipiélago de San Bernardo. 3.2. Redes familiares. 3.3. La movilidad religiosa. 3.4. Circulación de objetos. Conclusión. Bibliografía.

\section{Introducción}

La mayoría de las investigaciones recientes sobre las sociedades insulares en Colombia, se concentran en el conflicto étnico y político que existe en el Archipiélago de San Andrés, Providencia y Santa Catalina (Valencia, 2002, 2011; González, 2003; Guevara, 2007; Leiva, 2004; Rivera, 2002). En gran medida, este interés responde a los procesos de reivindicación étnica que surgieron en el marco de la Constitución Nacional de 1991. Allí se establecen los derechos especiales de las poblaciones raizales, es decir, los habitantes que se reivindican como nativos ancestrales de dicho archipiélago. En la mayoría de estos análisis, el territorio y el espacio aparecen como temas transversales a las reivindicaciones étnicas locales. Por ejemplo, González (2003) le ha prestado especial atención al estudio de la apropiación del espacio y a su relación con los procesos identitarios que allí tienen lugar. No obstante, aún sigue siendo escaso el interés por los procesos de territorialidad insular, que tanto en San Andrés ${ }^{1}$ como en otras islas, ocurren por fuera del contexto de la etnicidad. Desde nuestra perspectiva, el análisis de los dichos procesos resulta fundamental para entender la coexistencia de identidades y prácticas territoriales que desbordan las fronteras geográficas, identitarias y sociales de las poblaciones insulares.

En este contexto, el presente trabajo se interesa por la apropiación del territorio y la espacialidad entre la población del Islote (Caribe colombiano). El objetivo es describir y analizar cómo los isleños - forma en que se identifican sus habitantesse apropian de su espacio insular y continental. Por apropiación entendemos las

\footnotetext{
${ }^{1}$ Una excepción es el trabajo de Guevara (2009) que analiza las redes isleñas sanandresanas que existen en Bogotá.
} 
prácticas de ocupación, uso y organización que los isleños le otorgan a cada una de las islas de su entorno, es decir a su territorio ${ }^{2}$. Pero los isleños también se movilizan a otros territorios costeros, creando redes turísticas, familiares, comerciales y religiosas, con las cuales crean distintas interacciones. Estas últimas nos hablan de su relación singular con otros espacios, es decir, de sus prácticas más amplias de espacialidad (Cailly, 2009: 151-156). La articulación de los distintos territorios por medio de las prácticas de apropiación y espacialidad es lo que aquí denominamos espacio isleño. Retomando el concepto clásico de Lefebvre (1991 [1974]) entendemos por espacio el producto de la interacción de diferentes prácticas culturales, así como de distintos procesos políticos, sociales e históricos. Es decir, el espacio isleño está, además, condicionado por las imposiciones (políticas y sociales) de la sociedad nacional. Por otro lado, este espacio no se limita a la producción del territorio isleño. Pues la movilidad, las estadías temporales y las interacciones cortas articulan estos otros territorios al espacio isleño sin pasar necesariamente por su apropiación ${ }^{3}$.

Para ilustrar lo anterior este trabajo se divide en tres partes. En la primera presentamos datos generales de la historia, la geografía y los antecedentes etnográficos sobre el archipiélago. La segunda parte es la descripción y el análisis de las formas de apropiación del territorio insular por parte de los isleños. Ésta, se concentra en las cuatro islas donde tienen mayor incidencia los isleños (Islote, Múcura, Tintipán, Ceycén). Posteriormente, describiremos las relaciones y contactos de los isleños con dos territorios costeros (Tolú y Cartagena) por medio del turismo, las redes familiares y la circulación de objetos y personas.

En las ciencias sociales el Islote solo ha despertado el interés de dos antropólogos. El primero de ellos fue el panameño Stanley Heckadon (1970), quien realizó la primera etnografía sobre las dinámicas pesqueras. Posteriormente Oriana Alonso (2010) investigó sobre el papel del humor en la vida social isleña. Estos estudios son ricos en análisis y aspectos etnográficos sobre la isla. Sin embargo, aunque describen generalidades de las otras islas, no es posible encontrar en ellos mayores referencias a la relación de los isleños con el resto del archipiélago ni con los territorios costeros. Por eso, para este trabajo me baso principalmente en el material que recolecté ${ }^{4}$ durante mi trabajo de campo en el Islote entre los meses de febrero y noviembre del 2010 y julio-septiembre del 2011. Durante este tiempo tuve la opor-

\footnotetext{
${ }^{2}$ Utilizamos la definición de territorio de Agnew: "un espacio social con límites ocupado y usado por diferentes grupos sociales como consecuencia de sus prácticas de territorialidad o el campo del poder ejercido sobre el espacio por las instituciones dominantes" (1994: 620).

${ }^{3}$ A excepción de algunos barrios donde los isleños tienen casas y los conciben como "propios" aunque queden en otras ciudades y solo los habiten temporalmente.

${ }^{4}$ Que combinó la observación participante, el levantamiento de datos históricos y genealógicos y la realización de entrevistas semiestructuradas, así como la etnografía en las casas isleñas que se ubican en Cartagena, Tolú y Rincón (ver Mapa 1).
} 
tunidad de observar y participar de la vida de los isleños. Aunque el punto de estadía principal fue el Islote, pude movilizarme junto con individuos y familias isleñas a los territorios insulares y algunos costeros con los que éstos tienen contacto. Estos desplazamientos me permitieron ser testigo y parte de las trayectorias de los isleños. Así, fui partícipe de los intercambios y las relaciones con otros territorios. Se puede decir que la movilidad que tuvo mi etnografía es una expresión de la movilidad de la vida social isleña.

\section{El archipiélago de San Bernardo: presentación geohistórica}

El archipiélago está conformado por las islas de Boquerón, Isla Palma, Ceycén, Mangle, Panda, Maravilla, Múcura, Tintipán y El Islote y Tiene una distancia de 70 kilómetros hacia el suroccidente de la ciudad de Cartagena (Bolívar) y de 30 kilómetros con Tolú (Departamento de Sucre).

Después de la isla de Maravilla, El Islote es la isla más pequeña del archipiélago con una hectárea de superficie. Es una isla artificial que concentra la mayor parte de población ( 800 personas).

Sus habitantes actuales son el resultado del poblamiento tuvo inicio en la segunda década del siglo XIX, cuando se comenzaron a instalar gradualmente distintos pescadores provenientes de Barú ${ }^{5}$ conocidos como baruleros. Según Martínez y Uribe (1970) la expansión de los pescadores baruleros hacia el archipiélago de San Bernardo tuvo lugar después de la abolición definitiva de la esclavitud en la Nueva Granada en 1851. Sin embargo, esta afirmación no tiene bases etnohistóricas ni registros de la historia oral que la sostengan. No obstante, las narraciones, tanto de los baruleros mayores como de isleños, nos hablan sobre ciclos de viaje que emprendieron desde Barú los individuos de dos familias con el fin de buscar nuevos lugares para pescar y cultivar coco, pues el comercio de este producto tuvo su auge en el Caribe entre finales del siglo XIX hasta la primera mitad del XX. En este proceso, los baruleros se fueron apropiando gradualmente de Tintipán y Ceycén como islas propicias para el cultivo. Así, viajaban al final de los veranos ${ }^{6}$, para aprovechar la brisa del noreste y regresaban antes de que terminara el invierno, antes de que soplaran los vientos Alisios (dirección Norte-Sur) pues de lo contrario sería más difícil volver a Barú.

\footnotetext{
${ }^{5}$ Población ubicada al suroccidente de Cartagena (ver Mapa 1).

${ }^{6}$ El archipiélago de San Bernardo tiene un clima tropical seco. Presenta dos estaciones. La estación seca comienza en noviembre y se extiende hasta mayo. La estación invernal comienza en mayo y se extiende hasta octubre. En junio existe un pequeño periodo seco denominado “veranillo de San Juan”.
} 
Mapa 1. Ubicación del Archipiélago de San Bernardo

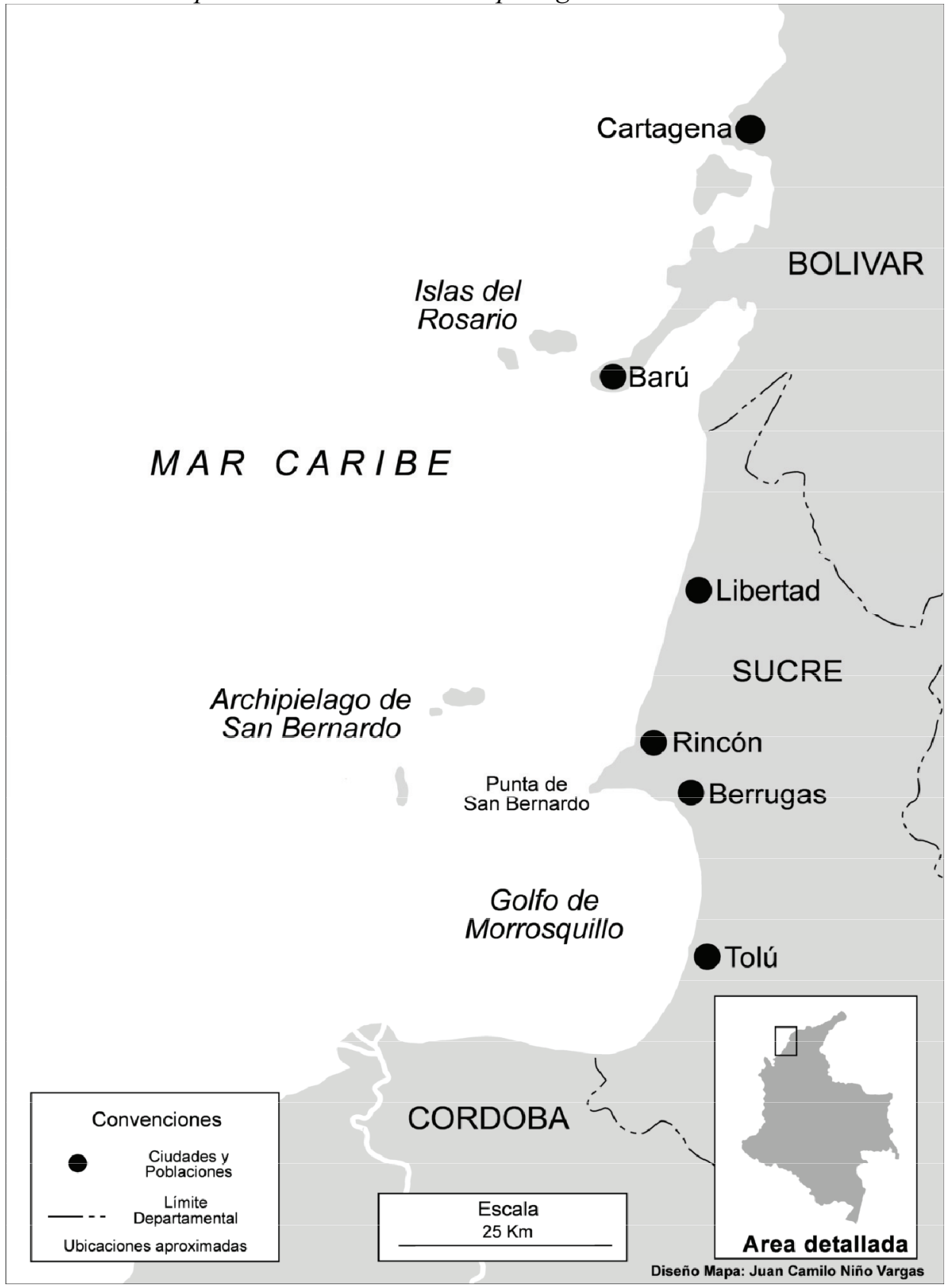


Paradójicamente los primeros pescadores escogieron la isla más pequeña del archipiélago como lugar de asentamiento. El argumento común de los historiadores locales para justificar esta elección es la ausencia de mosquitos en el Islote. Pues como está consignado en los reportes de expedición Fidalgo el Islote era a principios del siglo XIX el único cayo libre de manglar y con poca vegetación en el archipiélago. Esto implicaba una menor presencia de mosquitos en el Islote que en las islas y cayos vecinos. La instalación de los ranchos de palma y madera que hicieron los primeros baruleros fue un proceso gradual en el que los pobladores agrandaron la isla con rellenos de residuos sólidos. Este proceso se denomina calzar y será descrito en la segunda parte del artículo.

A nivel administrativo el Islote es un corregimiento $^{8}$ del Distrito Cultura y Turístico de Cartagena. En este sentido, a pesar de su distancia con esta ciudad capital del Departamento de Bolívar está supeditada a la misma. Por otro lado, el archipiélago está ubicado dentro de un Área Marítima Protegida de carácter submarino, que lleva como nombre Parque Nacional Natural Corales del Rosario y San Bernardo, y que está bajo la jurisdicción de la entidad de carácter público Parques Naturales Nacionales de Colombia. En este sentido, el Islote también está supeditado a las legislaciones ambientales que regulan la pesca y la explotación de los recursos marinos. Aunque aquí no profundizaremos en estas dos dimensiones, es necesario tenerlas en cuenta para entender las prácticas locales de apropiación y ordenamiento ${ }^{9}$ del espacio isleño. Pues al margen del ordenamiento estatal, surgen otras formas de ordenamiento espacial (Herrera, 2002: 26) que desbordan y, en algunos casos, contradicen el "deber ser" de la normatividad estatal. Aquí, nos concentraremos fundamentalmente en el modelo de ordenamiento del espacio isleño por parte de los pobladores locales.

\footnotetext{
${ }^{7}$ Heckadon (1970) reproduce un extracto de los escritos del Expedición del Brigadier de la Armada española José Joaquín Fidalgo que fue una de las empresas científicas más importantes patrocinadas por los Reyes de España en la segunda mitad del Siglo XVIII. En este extracto se señala la presencia de un cayo que Heckadon identificó como el Islote por su posición geográfica. En el Extracto se afirma que dicho cayo "no está inundado y hay en él otros árboles y pocas palmas de coco" (Heckadon, 1970: 15, citando los derroteros de la Expedición Fidalgo s.f).

${ }^{8}$ Un corregimiento en Colombia es "una división del área rural de un municipio con una población considerada dentro de los Planes de Ordenamiento" (DANE, s.f).

${ }^{9}$ Herrera (2002) toma el concepto de landscape propuesto por Duncan, quien lo define como un "modelo culturalmente producido de cómo debe estar organizado el entorno" (Duncan [1989], citado y traducido por Herrera (2002: 26) en la nota al pie $n^{\circ}$. 49) y le introduce unos matices para referirse, no solo al modelo de ordenamiento del Estado colonial que ella analiza sino también los modelos que coexistían en las regiones consideradas en su estudio. Aquí retomamos el planteamiento de Herrera, pero nos referimos al "ordenamiento estatal" enmarcado en la normatividad actual — donde el Islote aparece como corregimiento- y al "ordenamiento isleño" que realizan los isleños en su territorio.
} 


\section{Formas de apropiación territorial del archipiélago}

Como se puede ver en el Mapa 2, el Islote se encuentra entre las islas de Tintipán y Múcura. La isla de Ceycén está ubicada al sur del archipiélago a una distancia aproximada de 8 kilómetros.

Mapa 2. El Archipiélago de San Bernardo

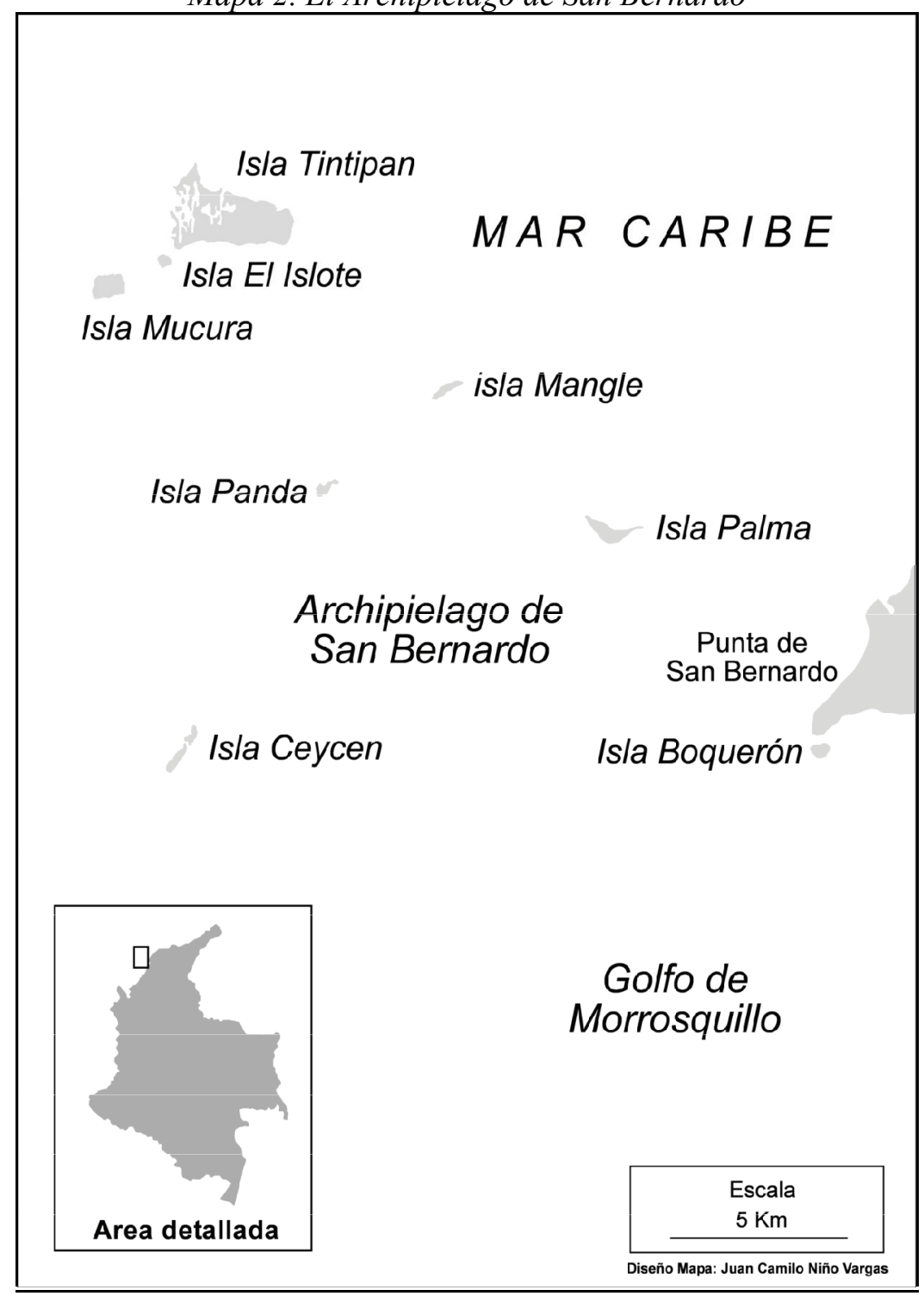


En este apartado nos concentraremos en la descripción y análisis de la relación de los isleños con estas cuatro islas (Islote, Ceycén, Tintipán y Múcura). Aunque los isleños se movilizan por todo el archipiélago, mantienen una relación particular de apropiación territorial, ordenamiento espacial e interacciones sociales con estas cuatro islas.

La primera parte de esta sección se concentra en la descripción y el análisis de las formas de apropiación y ordenamiento espacial en el Islote, para entender el significado que tiene cada isla en la configuración social isleña.

\subsection{El Islote: la capital del archipiélago}

En la Ilustración 1 podemos ver una de las tantas fotografías del Islote que circulan en internet. Esta isla tiene una demografía densa, pues alberga 800 personas $^{10}$ en una hectárea. No obstante el confinamiento que ofrece la imagen se desdibuja con la observación prolongada y el análisis de las dinámicas sociales internas. Aquí, pretendo mostrar las características del ordenamiento local que los isleños otorgan a su espacio insular y con estas, entender por qué los isleños y los habitantes de las islas circundantes conciben al Islote como "la capital del archipiélago".

\section{A) Apropiación del Islote: "calzar" y "echar corral"}

Como lo señalamos anteriormente, desde la llegada de los primeros pobladores en las últimas décadas del siglo XIX la apropiación del terreno residencial implicó la práctica de calzar, es decir rellenar el mar con residuos sólidos y cerrarlo ${ }^{11}$ o echar corral. Estas siguieron siendo las formas en que los isleños se apropiaron poco a poco del mar para volverlo habitable. Así lo narraba el señor Miguel Felipe Morelos, más conocido como "El Tío Pepe", el isleño de mayor edad hasta el año 2011 (murió de 97 años). Él era considerado el portador principal de la memoria isleña:

Yo si iba calzando como yo sabía que iba a tener un poco de hijos [...] si porque a pesar que tengo un poco (de hijos) aquí (en el Islote) [...] yo cerré [...] como aquí

\footnotetext{
${ }^{10}$ Estos son datos que resultaron del censo personal. Para el año 2005, el Departamento Nacional de Estadística registraba una población de 520 personas (DANE, 2005).

${ }^{11}$ Cerrar en el contexto isleño significa cercar o contener el suelo calzado con cercas de madera que se disponen de forma vertical enterrándose en el fondo marino. Estas están atravesadas horizontalmente con palos de madera que se atan para sostener el suelo de la isla. En algunas partes, estos muros son vigas de cemento que están atravesadas en su parte superior por un bloque largo que las bordea.
} 
[habla de su vivienda], aqui hay dos casas, este es calzado mío, de mis hijos (Entrevista personal, 1 de marzo de 2010).

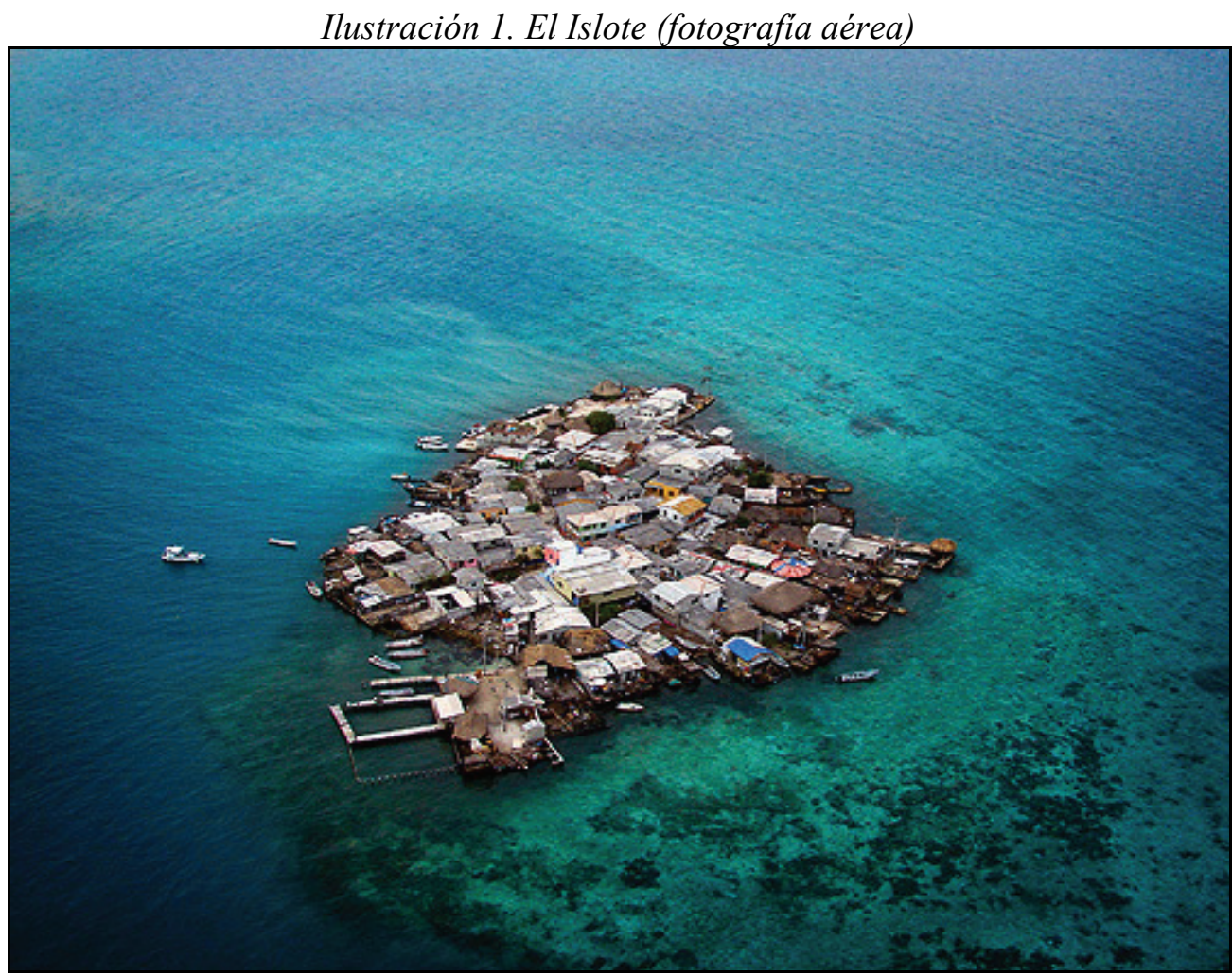

Fuente: URL <http://cartagenanativa.blogspot.fr/2010/10/santa-cruz-del-islote-colombia.html>.

En su testimonio, el "Tío Pepe" nos cuenta cómo el calce se realizaba a medida que las familias se iban ampliando. El terreno donde él continuó el calzado pertenecía a su madre, quien era nativa del Islote. La motivación principal para calzar fue asegurar el terreno para heredarlo, así lo señala cuando afirma que él calzó porque sabía que "iba a tener un poco de hijos". Por otro lado, la frase final "este calzado es mío" es una forma de mostrar que la propiedad sobre el suelo estuvo condicionada en un principio al acto de calzarlo ${ }^{12}$. Así, a partir de la ocupación inicial que llevaron a cabo los primeros pobladores, se fueron trazando las fronteras internas de la

\footnotetext{
${ }^{12}$ Actualmente, muchos de los terrenos calzados son arrendados o vendidos a otros isleños y el calzado es una actividad reducida.
} 
isla que están determinadas por la presencia de diferentes grupos de viviendas. Éstos fueron creciendo a medida que iban formándose nuevas uniones, ya sea entre hombres y mujeres isleñas, o entre hombres y mujeres isleñas con personas venidas de otros parajes.

Por otro lado, el acto de calzar ${ }^{13}$ y cerrar el suelo isleño muestran la condición cambiante del tamaño de la isla y su la transformación de los espacios acuáticos en espacios "secos". En el siguiente relato de la señora Elida Castillo, una de las mujeres mayores que es cabeza de una familia extensa con una buena parte de terreno propio:

Esto era un puerto [señala los alrededores de su vivienda] esto era pura agua, entonces mi papá me dio un pedacito [...] y yo fui echándole tierra, rellenándolo, pero todo esto era agua. Lo fui rellenando con piedra, con palo, venían unas trozas [troncos] grandísimas que sacaban madera [...] y que salían de los ríos cuando se crecian $^{14}$ e iban y las traían y hacian corral [...] y ahi iba echando piedra, iba echando caracolejo ${ }^{15}$, caracol. Ya cuando ya estaba seco, se cogía la basura ${ }^{16}$. Un señor que hacía botes recogía la basura y así fui agrandando y agrandando [...] cuando mi papá me lo dio así tenía 4 metros (cuadrados) y ahora tiene nueve. Y entonces sequé allá donde está Daniel (su hijo) y entonces luego donde esta Chavelo (otro hijo), sequé ésta de Marciana (su hija) (Entrevista personal, 9 de abril de 2010).

Así, la isla pasó de ser un terreno compuesto de "pura agua" a un terreno "seco". Al volverla "seca" y habitable esta creció gradualmente. El crecimiento es evidente si tenemos en cuenta que en 1970 el Islote tenía $7.500 \mathrm{~m}^{2}$ (Heckadon, 1970: 2), y actualmente se cuentan $10.000 \mathrm{~m}^{2}$ aproximadamente. Tal situación, condujo también a un incremento del $250 \%$ en el número de viviendas construidas. Así, en 1970 había 38 viviendas (Heckadon, 1970: 39) en la isla, y actualmente éste número asciende a $98^{17}$.

Este tipo de apropiación generó una distribución disímil del espacio en el que unas familias calzaron más terreno que otras. La dinámica de apropiación de terrenos dependió, como lo vemos en los apartes presentados arriba, de la cantidad de hijos a quienes se destinaría el pedazo de tierra, así como al trabajo familiar y las posibilidades de conseguir el material suficiente para "calzar" o "secar" el terreno como lo vemos en el extracto anterior.

\footnotetext{
${ }^{13}$ Esta acción también es llamada en la isla "secar", "rellenar" o "aterrar".

${ }^{14}$ Habla de los troncos grandes de madera que llegaban con las corrientes en épocas de lluvia, cuando se desbordaba el río Sinú. Éste nace en el Departamento de Antioquia y desemboca en el mar Caribe, más exactamente en las costas del Departamento de Córdoba.

${ }^{15}$ Piedra pequeña producto de la solidificación de los corales.

${ }^{16}$ Los residuos sólidos también sirvieron como relleno del suelo isleño.

${ }^{17}$ Datos recolectados durante el trabajo de campo personal.
} 
Al igual que el proceso de calzado, la construcción de las casas también fue un proceso gradual y paralelo al surgimiento de nuevos núcleos familiares. A cada nueva unión, los esposos buscan ampliar el suelo o construir su casa en el suelo ya calzado por sus ascendientes consanguíneos (padres, abuelos) y construir una nueva vivienda. El grupo de viviendas que comparten un territorio heredado por los padres entre varias hermanas y hermanos es representado por los isleños como "un barrio". Los límites que los separan son "calles" y "callejones" y los espacios costeros son representados como patios o puertos. Estos elementos componen el ordenamiento espacial isleño.

\section{B) Ordenamiento espacial del Islote}

Al ingresar al Islote desde el puerto principal (Puerto de Helena) - en el costado suroriental- aparece ante nuestros ojos la "Calle de la Cruz" que es la más grande de la isla y la atraviesa de este a oeste. Siguiendo por la calle de la Cruz se llega a la Plaza de la Cruz que es el lugar central de la vida pública isleña. Allí reposa la patrona de los isleños: La Cruz de Mayo. Alrededor de ésta, se celebran las fiestas patronales de la isla en fechas específicas. Sin embargo más allá de su carácter religioso, esta estructura es una insignia cultural de los isleños que fue instalada desde el poblamiento de esta isla en el siglo XIX. Por esta razón, el Islote también es conocido como "El Islote de Santa Cruz".

Una vez en esta plaza es posible apreciar callejones que comunican las casas entre sí. Aunque hay patrones que se repiten en algunas casas, la mayoría de estas son de materiales, tamaños, colores y formas disímiles. Así, para un hombre isleño que vive solo y cuenta con una porción de terreno heredada de sus padres, su "casa" puede ser un pequeño rancho de madera y palma donde duerme y guarda sus objetos personales. Mientras tanto, otras personas isleñas pueden vivir con su familia nuclear $^{18}$ en una casa que cuenta con dos o tres habitaciones, cocina y salón. Otros grupos viven en familias extensas ${ }^{19}$ en una misma casa con dos o tres plantas y/o habitaciones donde puede llegar a dormir una sola persona o una pareja con sus hijos. En las casas construidas de cemento, es habitual la presencia de un solar o terraza que conduce a los callejones internos de la isla. Allí los isleños descansan, comen y discuten cuando llega la tarde.

\footnotetext{
${ }^{18}$ Compuesta por padre y madre, o padres e hijos. No obstante esta figura es variable en el Islote, pues hay parejas que se encargan de la crianza de sobrinos y nietos además de la de los hijos. Hay casas donde solo habita una mujer o un hombre y que es objeto de la estadía periódica de los parientes que vienen de otros territorios.

${ }^{19}$ Me refiero a la estructura de parentesco donde varios parientes de distintas generaciones habitan en un mismo espacio residencial.
} 
En la mayoría de casos, las viviendas cuentan con una porción de terreno adicional que se abre hacia el mar y que es reconocido como un "patio". Este espacio es utilizado para varias labores como la cocina con leña, el lavado de la ropa, la preparación del pescado, el estacionamiento de las embarcaciones o como sitio de reunión en el momento de la cena cuando llega la tarde y el sol se comienza a esconder en el horizonte.

El suelo de los patios se confunde con el mar en la época de lluvias que va de mayo hasta fines de octubre. Esto se debe a la baja elevación que tiene la isla, pues el suelo calzado no alcanza una altura mayor a los $60 \mathrm{~cm}$ sobre el nivel del $\mathrm{mar}^{20}$. En estos casos, la víspera del invierno obliga a muchos isleños a reforzar el relleno de los patios o a crear barreras de contención con piedras y conchas de caracol en las orillas para evitar la inundación de sus hogares.

Una de las formas en que los isleños identifican estos conjuntos de casas es dividiéndolos en barrios que llaman de formas distintas como "Pueblito", "Casablanca", "Villa Rosita", "El Oasis", "Pasacorriendo", por mencionar algunos. Con el paso del tiempo los isleños han adquirido una cierta identidad que se relaciona con su pertenencia a un barrio determinado. Por ejemplo una isleña se identificaba como "pueblitera" por ser proveniente del barrio "Pueblito". Esta representación interna del espacio articula elementos de la ciudad (como los barrios, la plaza central y la calle) y es utilizada en contextos específicos, como, por ejemplo, cuando se le pregunta al isleño sobre la ubicación de su vivienda. Sin embargo, hay otra manera de representar el espacio del Islote por la mención de sus espacios costeros como los puertos.

\section{C) La representación espacial por puertos}

Como muestra la Ilustración 2, los isleños también identifican su isla por medio de puertos que se ubican en varios puntos cardinales de la isla. Los puertos son los lugares donde los isleños descargan pescado, anclan sus botes y desembarcan distintos tipos de mercancía. Tienen extensiones variadas ${ }^{21}$ y sus nombres corresponden a los propietarios de cada uno de ellos.

\footnotetext{
${ }^{20}$ Según Heckadon (1970), cuando realizó su investigación, el Islote no presentaba una elevación mayor a dos pies $(60 \mathrm{~cm})$.

${ }^{21}$ Por ejemplo, aunque no se cuenta con medidas exactas de cada puerto, el "Puerto de Helena" (ver ilustración 2) es el más grande de la isla y el más cómodo para el desembarque de turistas, mercancía, agua, y distintos productos que llegan semanalmente a la isla. Se trata de una amplia construcción en cemento. Mientras tanto, puertos como "Rosalinda" y "Elida" son utilizados para el anclaje de pequeñas embarcaciones de pesca, así como para el baño de los isleños en el "agua salada" así como para el desembarco de pescado y personas isleñas, pero no son usados como punto de desembarco de turistas.
} 
Ilustración 2. El Islote según Mariana de Hoyos

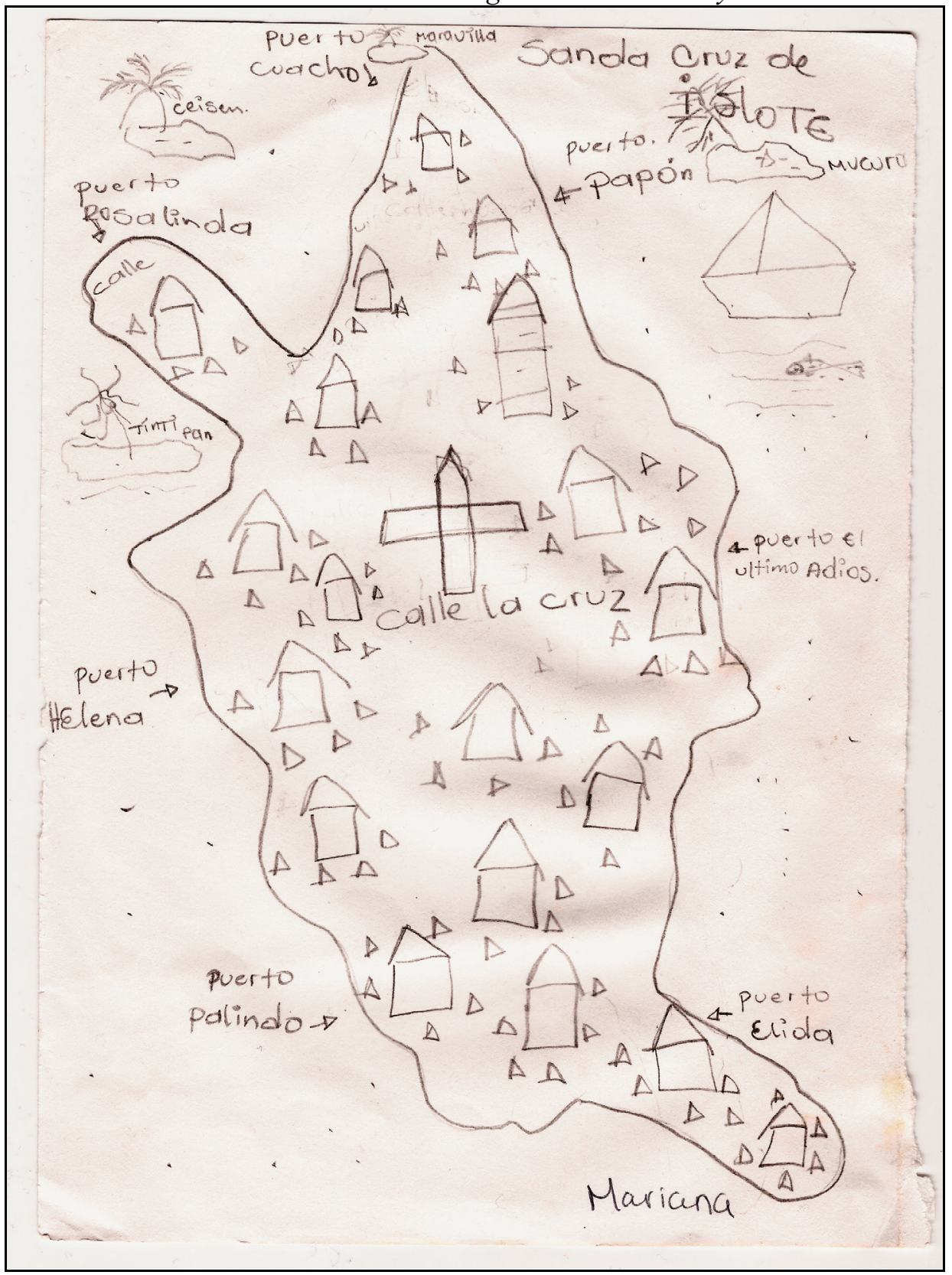

Fuente: Realizado por la isleña Mariana de Hoyos por petición personal de la antropóloga (Material recolectado durante la segunda fase del trabajo de campo, 2011). 
No existe una razón específica para determinar por qué estos puertos son reconocidos bajo los nombres de unas personas de la familia y no de otras. Sin embargo, en unos casos (como el "Puerto Elida", "Puerto Rosalinda" o "Puerto Elena") se trata de lugares donde la cabeza principal del grupo residencial son las mujeres mayores que le dan el nombre a cada puerto. En el caso del "Puerto Papón", "Puerto Guacho" o "Puerto Palindo", los hombres que le dan nombre son reconocidos por tener el monopolio de actividades comerciales como la compra-venta de pescado y la venta de víveres. Esta forma de caracterizar el espacio es la más utilizada en el plano cotidiano isleño y constituye una representación hacia afuera del Islote con respecto al mar y las dinámicas que se relacionan con este a través de los puertos. Mientras tanto, la identificación por "barrios" pasa a un segundo plano en la mayor parte en las cartografías locales.

El Islote combina entonces la marcada presencia de las casas en cemento - y unas pocas en palma y madera- con la ausencia casi total de vegetación, a excepción de pequeños árboles que sobreviven con esfuerzo frente a algunas casas y que aportan un poco de frescura al escenario caluroso y poco sombrío del Islote. Todos estos elementos, que se articulan en la imagen de puertos, barrios y calles, son evocados por los isleños y sus vecinos de otras islas como aspectos próximos a la idea de la "civilización". Esta condición contrasta con la percepción de las islas circundantes, donde Tintipán, por ejemplo, ocupa el lugar del "monte" en el espacio isleño.

\subsection{Tintipán: la apropiación y uso del "monte"}

Desde la costa norte del Islote se puede divisar el manglar que recubre la mayor parte de Tintipán. La sensación de calor extremo en el Islote debido a la ausencia casi total de vegetación contrasta con la frescura que evoca Tintipán; pues mientras el suelo y las casas del Islote están construidas, en su mayoría, en cemento, Tintipán presenta una vegetación abundante que mezcla varias especies de mangle ${ }^{22}$ con terrenos "firmes" donde se imponen altas palmas de coco y donde algunos miembros de familias adineradas han construido cabañas de recreo.

Además de la impresión de espesura que le otorga el abundante manglar, Tintipán tiene otros elementos por los cuales es reconocida como "el monte". En primer lugar, tiene ensenadas que contienen el agua "turbia", fría y quieta que contrasta con el agua clara y móvil y pandita, es decir clara, que se encuentra en las playas y los exteriores de esta isla. Los isleños se sumergen en las aguas de las ensenadas

\footnotetext{
${ }^{22}$ Mangle rojo (Rizophora Mangle), mangle negro (Avicennia germinans) y mangle blanco (Laguncularia racemosa).
} 
para caretear y arponear ${ }^{23}$ algunos peces que se encuentran en las raíces de los manglares, pues estos son hábitats propicios para el refugio de peces arrecifales como los pargos y las picúas (barracudas) (UAESPNN: 2006). Si navegamos entre los manglares, podemos encontrar la presencia de ciénagas fangosas y difíciles de transitar, que le otorgan un ambiente de oscuridad a la isla y por las cuales los isleños se pasean en canoas en viajes solitarios. No obstante, la presencia de manglares atrae una gran cantidad de mosquitos llamados localmente plaga o jejenes que abundan en horas de la tarde. Estos son invasivos hasta tal punto que los isleños que habitan en Tintipán deben acudir a medidas como quemar conchas de coco para espantarlos con el abundante humo o devolverse al Islote hasta las horas de la noche cuando ya ha bajado el nivel de mosquitos en esa isla.

En segundo lugar, está la presencia de animales como las iguanas y un tipo de mapache llamado localmente mundano. Estos últimos son difíciles de atrapar e implican expediciones largas y silenciosas sobre todo en el verano. Pues es en ésa época cuando se encuentran en su mejor punto de nutrición y son utilizados - aunque muy rara vez- para el consumo. Esta condición inaprehensible de los animales que habitan en Tintipán, aumenta su connotación como el monte.

Por otro lado, se encuentran vestigios de antiguas propiedades de antiguos narcotraficantes. Estos edificios fueron construidos durante el auge de tráfico de cocaína en los años 1980 en Colombia ${ }^{24}$. Sin embargo, a medida que sus propietarios fueron capturados por las autoridades, el Estado se los apropió bajo la figura de "extinción de dominio" 25 . Ahora sólo es posible ver en éstos un paisaje disímil de ruinas de cemento que se mezclan con la maleza que los ha cubierto con el tiempo. Los isleños fueron testigos del paso de estas figuras por la isla y traen a la memoria relatos que hablan de la ostentación de éstos personajes.

El cuarto elemento que identifica a esta isla es la presencia del cementerio. En un primer momento los muertos eran enterrados en las parcelas de coco que se comenzaron a cultivar desde el siglo XIX durante el auge del comercio de este fruto. Posteriormente, como lo cuenta el "Tío Pepe", los isleños comenzaron a concentrar los mausoleos en una parcela que pertenecía a una familia de la costa colombiana, y a partir de ahí establecieron este lugar como su cementerio.

\footnotetext{
${ }^{23}$ Método de pesca que se usa en algunos casos para atrapar peces grandes que se encuentran en los arrecifes o las raíces de los manglares, como la picúa o barracuda. Estos arpones son rifles de aire comprimido de distintos niveles y tamaños.

${ }^{24}$ La década de 1980 fue una de las etapas más agudas del narcotráfico en Colombia, esta vez de cocaína —en los años 1970 se trató de la marihuana-. En este periodo, los miembros de los cárteles de la droga que se concentraban en la ciudad de Medellín y Cali construyeron ostentosas propiedades, muchas de ellas en diferentes lugares del Caribe.

${ }^{25}$ Es definido por la Ley 793 de 2002 (Congreso de la República de Colombia, 2002) como la pérdida del derecho de dominio de un individuo o grupo sobre sus bienes por varias causas. En este caso es debido a su origen ilícito.
} 


\section{A) El cementerio: el monte como espacio ritual}

Navegando desde el costado nororiental del Islote hacia Tintipán, es posible divisar en ésta última, un muelle de madera que indica la entrada al cementerio de los isleños que sigue las pautas católicas. En medio de dos arcos blancos de cemento se insinúan algunas tumbas elevadas de las cuales alcanzan un metro de altura; la mayoría de éstas constituyen mausoleos de las principales familias de la isla.

En el costado derecho de la entrada está dispuesta una escultura blanca del Sagrado Corazón de Jesús, mientras tanto, al otro costado reposa en el mismo estilo de cemento blanco y sobre un bloque de concreto la Virgen del Carmen ${ }^{26}$. Detrás de estas figuras, se distinguen las cruces de madera que indican el nombre y la fecha de la muerte. Están dispuestas sobre las tumbas y algunas acompañan decoraciones importadas de poblaciones costeras como Cartagena, Tolú y Rincón. Unas son placas en hierro con inscripciones con el nombre o palabras que honran la memoria del fallecido. Otras tienen menos elementos decorativos y llevan una inscripción grabada en el bloque de cemento de las tumbas, que llevan en su mayoría flores o alguna planta pequeña sembrada al lado. El suelo del cementerio es arenoso pues la maleza y la vegetación anterior fueron removidas para construir las tumbas, entre las cuales se insinúan árboles aislados y pequeños. El cementerio está separado del manglar que lo rodea por un muro detrás del cual solo se percibe el verde abundante de tipos mixtos de ésta especie.

El ritual de enterramiento implica el paso de una procesión dentro del Islote que tiene continuidad con el trayecto por vía marítima hacia el cementerio de Tintipán. A continuación ofrezco una descripción breve de este trayecto, con el fin de mostrar el ritual de la muerte como una práctica que articula al Islote con Tintipán:

El primer día, se vela al cuerpo que reposa frente al altar dispuesto en la sala de la casa o la habitación del muerto. Posteriormente, se espera máximo hasta el día siguiente para el entierro debido a la dificil conservación del cuerpo en las condiciones de la isla donde se carece de energía y las temperaturas son elevadas. La velación es dirigida por una rezandera ${ }^{27}$ isleña o contratada en Tolú o Rincón. Acto seguido, los familiares cargan el ataúd y comienza una procesión dentro del Islote en donde los familiares recorren las calles principales y pasan por las casas por las

\footnotetext{
${ }^{26}$ Patrona de los transportistas en Colombia. En éste caso es la patrona de los pescadores.

${ }^{27} \mathrm{La}$ rezandera es una figura común en diferentes zonas rurales de Colombia. Esta práctica implica el conocimiento del ritual y de las oraciones para dirigir, en este caso, la novena católica en la que se vela al fallecido. En el Islote, sólo hay dos mujeres consideradas como rezanderas. Sin embargo, una de ellas ya renunció a éste oficio por su avanzada edad y la otra - a quien la primera transmitió este conocimiento-, también renunció porque se encuentra en proceso de conversión a la doctrina evangélica. Por eso, en dos de los tres entierros de los que fui testigo, fue necesario contratar una rezandera venida de Tolú y pagada con las contribuciones de varios familiares y amigos.
} 
cuales el muerto vivió o con las que tenía mayor relación. La procesión acompaña al muerto hasta la "Calle del Último Adiós" donde lo espera una gran chalupa ${ }^{28}$ decorada con flores y una cruz de madera. A la chalupa suben algunos de sus familiares cercanos y detrás de ella se movilizan diferentes lanchas que parten silenciosas y dan continuidad a la procesión por vía marítima. La familia del difunto ingresa en primer lugar al cementerio, prosiguen los parientes cercanos. Una vez adentro, las mujeres lloran no solo al muerto del momento sino a la memoria de todos sus familiares muertos, asi que aprovechan para visitar y arreglar las otras tumbas mientras la familia del difunto se instala en el lugar escogido para el entierro en un corto ritual que algunas veces acompaña la rezandera emitiendo oraciones cortas. Otras veces el ritual se lleva a cabo por los mismos familiares que lloran sobre las tumbas y rememoran eventos de la vida del muerto y el dolor por su pérdida en medio de un llanto desgarrador que es acompañado por los acompañantes. Una vez enterrado el cuerpo, las personas abandonan poco a poco el cementerio y regresan al Islote para continuar con la velación que ahora se llevará a cabo frente al altar. Esta durará hasta la novena noche cuando se realiza el levantamiento del altar que indica la salida del alma del difunto por la puerta de su casa y su descanso eterno (Cuaderno de campo, información resumida de la observación de tres entierros en junio y octubre de 2010).

Los ataúdes así como las coronas de flores son objetos transportados desde otros lugares como Cartagena o Rincón, y las tumbas son cavadas generalmente por una persona que se especializa en oficios de construcción y se encarga de mantener el cementerio. Cuando el muerto isleño viene desde otra ciudad, el proceso de velación se lleva a cabo de la misma manera en el Islote. Antes de su llegada los familiares disponen el altar y preparan el espacio donde reposará el ataúd durante el primer día mientras esperan en los puertos de la isla la llegada de la lancha que transporta el cuerpo del difunto.

Aunque breve, la descripción anterior muestra la apropiación de Tintipán como una de las dimensiones más importantes del espacio isleño. Pues combina lugares fangosos e intransitables (como el manglar, las aguas quietas y oscuras, los animales inaprehensibles y el lugar de los muertos isleños) con los espacios habitados y/o abiertos (como las cabañas turísticas y las playas y los lotes cultivados). A pesar de la presencia esporádica de turistas y permanente de las personas que trabajan en las cabañas turísticas de Tintipán, allí no hay un asentamiento permanente ni una población que se identifique como originaria de esta isla. Esta situación es distinta en la isla de Múcura que describimos a continuación.

\footnotetext{
${ }^{28}$ Esta es una embarcación de madera. En el caso de la chalupa utilizada para el transporte de los muertos isleños constituye una embarcación de gran tamaño con un motor fuera de borda y con capacidad para 15 personas.
} 


\subsection{Múcura: el espacio "salvaje"}

Desde el costado occidental del Islote se puede apreciar la isla de Múcura. Esta tiene 23 hectáreas y está conformada por una porción más grande de tierra firme que esta última. La isla, está separada en diferentes lotes que pertenecen en su mayoría a familias externas al Islote. Los lotes, como en el caso de Tintipán, tienen extensiones disímiles y los propietarios se han encargado de interponer cercas metálicas para delimitar los linderos de cada una de estas extensiones. Anteriormente estos lotes fueron apropiados por las familias que se establecieron en el Islote y que tenían cultivos de coco en Múcura a finales del siglo XIX. En esa época, la separación de los terrenos se hacía por medio de linderos naturales, como árboles. Esta situación cambió con la llegada de "la porroca", una enfermedad que acabó con los cultivos en la segunda década del siglo XX. Por eso, los isleños vendieron a particulares estos terrenos que, en su mayoría, fueron aprovechados para la industria turística.

Entre los lotes se distinguen algunas palmas altas de coco, que se levantan imponentes en medio de la vegetación de manglar, que es la más alta de las islas del archipiélago (entre 5 y 6 metros). Ésta combina la presencia de mangle blanco y el mangle rojo que le aportan a la isla un lado misterioso - a la par que intransitable por el fango-, sobre todo en la parte sur de la isla que posee una laguna salada o charca. Dichos terrenos son conocidos por su fertilidad para el cultivo de distintos frutos tropicales. En una época, fueron utilizados para la cría de ganado, cuyo dueño era un empresario cartagenero. Sin embargo, ahora no hay presencia vacuna en la isla y sólo existen cultivos aislados que se confunden con la maleza. Además de la fertilidad de sus suelos, Múcura está provista de pozos subterráneos que almacenan agua dulce que es aprovechada por los pobladores locales para el consumo.

La isla de Múcura tiene connotaciones ambiguas para los isleños. Por un lado, es una fuente muy importante de trabajo y de espacios ostentosos por la presencia de distintos puntos turísticos provistos de playas blancas y aguas transparentes; por ejemplo, existe un hotel de lujo donde trabajan distintas familias isleñas en labores de cocina y limpieza. Por el otro, tiene una connotación de oscuridad y "suciedad", donde se confunden la presencia de seres misteriosos en el monte ${ }^{29}$, el carácter denso del fango y del manglar y la presencia "salvaje" de un caserío dentro de la isla.

Para comenzar describiré la dimensión turística de Múcura y luego mostraré las implicaciones que tiene la presencia de los mucureros en el espacio isleño.

\footnotetext{
${ }^{29}$ Como el fantasma de un niño blanco que muchos dicen haber visto en varias partes de la isla.
} 


\section{A) La dimensión turística de Múcura}

El hotel más grande de la isla se ubica en su costado nordeste y tiene acceso a playas blancas y generosas que están restringidas para los isleños y abiertas para turistas de clase alta y media alta que llegan de las principales ciudades de Colombia y del extranjero. Allí trabaja una cantidad considerable de isleños que son contratados por temporada para realizar los servicios de aseo, servicio y cocina. Este hotel es administrado por un empresario proveniente de la ciudad de Medellín, que es un símbolo de autoridad y poder económico para los habitantes del Islote y los de Múcura. Dicho establecimiento acumula varios elementos que se suman a su figura de poder económico; pues además de amplios terrenos y playas, contiene en uno de sus extremos la sede de la Infantería de Marina en estas islas, llamada por los isleños "el Vietnam". En la misma sede viven algunos funcionarios de la entidad Parques Nacionales Naturales de Colombia, quienes portan uniformes y representan a la autoridad ambiental en las islas. Dicha entidad es conocida por los isleños como "el Medio Ambiente". Su presencia es casi imperceptible. Solo es notoria cuando estos funcionarios se desplazan a las playas esporádicamente, o cuando llevan a cabo actividades como los talleres con los pescadores.

A este hotel de lujo se suma otro de menor tamaño y menor reputación, así como una cabaña turística de bajo costo que fue una de las primeras infraestructuras turísticas en la isla. Cada una de estas presencias tiene niveles de poder muy distintos en la isla, siendo el dueño del hotel más grande quien controla casi en su totalidad el uso de las playas y de otros espacios en la isla. Dichas relaciones no están ausentes de conflictos, y la autoridad de dichas figuras que son en principio externas a la isla se pone constantemente en cuestión.

B) La playa de La Punta: eje laboral de los isleños

La presencia de estas relativamente grandes infraestructuras turísticas contrasta con las de la playa La Punta, que está ubicada en el sureste de la isla. Detrás de esta se extiende la laguna o "charca" de agua salada que se esconde entre un espeso manglar. Allí, trabajan de manera independiente los hijos de un isleño que tuvo varias uniones e hijos. Ellos se repartieron el espacio de la playa hace aproximadamente 30 años y con sus mujeres construyeron ranchos de base de cemento y techo de palma provistos de cocinas de leña o restaurantes donde preparan almuerzos para los turistas. Estos últimos embarcan en Tolú y pertenecen en su mayoría a la clase media proveniente de Medellín, Bogotá y en menor medida Cali. Tienen un acceso relativamente fácil vía terrestre a la costa del Golfo de Morrosquillo y por esto pueden viajar a costos cómodos hacia el archipiélago.

Los isleños que trabajan allí se desplazan diariamente hacia La Punta, que queda a 10 minutos en lancha del Islote. Desde lejos, esta playa tiene una vista colorida 
debido a la presencia de los restaurantes con sus columnas de madera pintadas de varios colores y cubiertos con techo de palma. Allí se pueden leer coloridos avisos con los nombres de los restaurantes isleños. La actividad se inicia desde las nueve o diez de la mañana cuando los trabajadores llegan a la playa. Así, las mujeres comienzan a rayar el coco para la preparación del arroz, otros isleños fritan el pescado y los plátanos para completar el plato que es vendido a los turistas desde el mediodía. Hacia las once de la mañana llegan las primeras lanchas turísticas, que los isleños esperan desde la orilla con pleno conocimiento del número de turistas que llegará cada día.

Los trabajadores de la playa tienen una comunicación constante con los dueños de las embarcaciones que transportan a los turistas desde Tolú, que son conocidos como lancheros. Estos son ejes fundamentales para el funcionamiento de las dinámicas laborales en la playa, pero también para el intercambio de los isleños con el mundo continental, como veremos más adelante. Los lancheros tienen una relación estrecha con los dueños de los restaurantes y pueden llegar a transportar en la temporada alta (diciembre, enero, junio-julio, semana santa) un número aproximado de 200 personas diarias (UAESPNN, 2006: 134).

En la La Punta la labor está dividida en dos grupos principales: los restauranteros y los careteros. El primer grupo incluye a los propietarios y a todos los que cocinan y sirven los almuerzos a los turistas. El segundo grupo está conformado por quienes llevan a los turistas a observar el fondo marino en un punto cercano de Múcura. Esta actividad se realiza a diferentes horas de la mañana.

Las diferentes ocupaciones tienen una demanda cada vez mayor dentro de los isleños debido a la escasez de producto marino, lo que obliga a los pescadores a combinar las faenas con las actividades turísticas. Por eso, existen momentos del año como las temporadas altas, en que esta sobrepoblación de trabajadores en $L a$ Punta genera desencuentros por el monopolio de los espacios y las actividades ofrecidas. Ante tal situación los isleños activan distintas estrategias para evitar la acumulación del dinero por parte de una sola persona o grupo en dicha playa, uno de estos, es el establecimiento de un relevo denominado "el pico y placa" ${ }^{30}$ por parte de los isleños, que consiste en un acuerdo que obliga a los trabajadores a quedarse en el Islote durante dos días de la semana para que otros tengan la posibilidad de sacar el provecho de las ganancias. Además de los careteros y restauranteros, es posible encontrar a los cocteleros. Estos se encargan de la venta de cebiches en dos pequeños puestos creados por ellos mismos. En La Punta también circulan

\footnotetext{
${ }^{30}$ El "pico y placa" al que me refiero aquí, está inspirado en una medida adoptada por la alcaldía de Bogotá, que ahora se extendió a otras ciudades, donde se establece la prohibición de circular en días específicos a los vehículos dependiendo del número en el que finalice la matrícula (placa) del mismo.
} 
constantemente distintas mujeres que venden postres típicos en compañía de sus hijos.

La sobrepoblación laboral de la playa de Múcura es un motivo de disgusto de muchos isleños que la usan con fines de reposo, pues la encuentran "bulliciosa" frente a Tintipán. Unos prefieren no trabajar allí ni frecuentarla debido a que la oferta de servicios es muy alta y esto genera conflictos entre los trabajadores. En su discurso con respecto a su entorno insular, los isleños comparan las playas tranquilas y silenciosas de Tintipán con el bullicio, los conflictos y la falta de espacio en la playa de Múcura. Tal situación influye en la percepción general de la isla, pues además de la densidad de la vegetación que se confunde con la existencia de puntos turísticos y tierras fértiles, se encuentra la sobreexplotación de una de las pocas playas adaptadas por los propios isleños para su sustento.

Al lado de la dimensión turística, Múcura cuenta con la presencia de un pequeño poblado que lleva como nombre "Chupundún", que es más conocido como el caserio. En éste convive una población cuyos miembros son conocidos localmente como los mucureros.

\section{C) El caserío y los mucureros: la representación del "salvajismo"}

El caserío Chupundún se encuentra en el costado sur de la isla y tiene un promedio de 200 habitantes. Su poblamiento comenzó con la instalación de una familia isleña, que creció con la llegada de nuevos habitantes provenientes de zonas costeras e insulares como Barú, Rincón, Tolú y Berrugas. Aunque las primeras familias tenían lazos de parentesco estrechos con los isleños, éstos se perdieron gradualmente con el paso de los años y con la llegada de los nuevos habitantesmucurero. Este hecho produjo la división del caserío en dos familias que muestran un alto nivel de endogamia. En el caserío es rara la presencia de apellidos propios del Islote y las uniones que predominan tienen como base parejas compuestas por personas provenientes de diferentes territorios costeros cercanos al archipiélago. Por esa razón, como afirmaba un reconocido líder de Múcura, los mucureros tienen percepción de que "los del Islote se sienten más nativos que la comunidad de acá (Múcura). Hay menos gente nativa acá que allá" (Comunicación personal, entrevista realizada en mi primera visita al Islote, 7 de julio de 2005).

Este sentimiento de "exterioridad" de los mucureros frente al arraigo que los isleños expresan por su territorio, incide en la percepción que los primeros le otorgan a su sociedad y a su isla dentro del archipiélago. Pues, por un lado, consideran que por ser una población de menos gente, la resolución de los conflictos es más fácil que en el Islote que muchos perciben como un lugar de "difícil vivir". Por otro lado, la condición natural de Múcura es evocada como más "agradable" por los mucureros frente a la ausencia casi total de vegetación en el Islote. Sin embargo, muchos consideran que el Islote tiene mayor presencia institucional y estatal, es decir mayor 
atención por parte del gobierno que Múcura. Esta situación hace que Múcura sea vista, incluso por sus mismos habitantes, como parte de la periferia frente a la centralidad que evoca el Islote.

Dicha circunstancia no provoca un conflicto explícito entre las dos poblaciones, pues isleños y mucureros comparten lazos económicos y de amistad que son notorios; por ejemplo, en las festividades locales cuando los mucureros llegan al Islote y comparten la bebida con isleños. Sin embargo, el hecho de afirmar que existe un grado de sentimiento de "nativos" de los isleños frente a los mucureros, implica la afirmación de una frontera identitaria entre las dos poblaciones. Ésta se cristaliza en varias situaciones. La primera es la percepción que los isleños tienen de la apariencia del caserío. Pues en éste, los grupos de familias extensas dividen los terrenos en diferentes ranchos donde se alojan las familias nucleares formando una sucesión de pequeñas casas que componen una gran unidad residencial de parientes. Estas casas son de madera y tienen techos de palma y suelos en arena. Se prolongan a lo largo de la playa y su imagen se combina con la presencia de palmas de coco que le dan sombra al caserío. En el interior del caserío, el suelo se torna pantanoso en épocas invernales, haciendo que una gran cantidad de agua repose estancada y aumentando así la presencia de mosquitos y enfermedades. Detrás de las casas de Múcura, se extiende un gran espacio concebido como el monte dentro de la isla, en donde la maleza se mezcla con las palmas de coco que sobresalen imponentes. Estos elementos físicos (el material de los ranchos, la presencia interna de pantanos, la erosión de las playas, la cercanía al espacio provisto de vegetación densa y pocos espacios abiertos -el monte-) han hecho que los isleños perciban al caserío como un espacio "salvaje".

El segundo elemento que marca la percepción de los isleños sobre el caserío es la personalidad social de los mucureros de la isla. Esta situación se hace evidente en contextos de encuentro entre los dos grupos, como los partidos de fútbol donde los isleños llevaban una gran parte del público, y las palabras y arengas en las que tanto mucureros como isleños comparaban su forma de jugar y reafirmaban su pertenencia a una u otra isla. También fue visible para mí en los cultos evangélicos donde las personas sacaban a relucir la presencia de brujas en Múcura y la necesidad de "limpieza" de dicha isla llena de "suciedad", palabra que en la isla designa el hecho de practicar la brujería. Otro espacio de confrontación entre los dos grupos son las fiestas donde surgen comparaciones acerca de la "buena manera de bailar" de los isleños frente a la de los mucureros. En otras ocasiones, esta relación se percibía en el encuentro entre los niños mucureros y los niños del Islote; el profesor se quejaba de la rivalidad que existía entre los dos grupos, la cual era notoria en actividades compartidas y organizadas por la escuela. Por eso, en la referencia general que los isleños hacen sobre Múcura, el caserío es visto como un espacio alejado de la civilización frente al Islote que es la capital del archipiélago. Así mismo, al estar alejados de la "civilización" los mucureros eran muchas veces concebidos como más próximos de la naturaleza por medio del adjetivo "montunos". Esta percepción 
se suma a la idea que muchos tienen de estos como una sociedad "cerrada" y poco móvil. En palabras de un isleño "ellos [los mucureros] son un circulo de gente [...] como cerrados [...] no han salido al mundo" (Comunicación personal, 16 de julio de 2011). Esta idea de los mucureros como "un círculo" de gente que "no ha salido al mundo" 31 contrasta con la movilidad y el nivel de "conocimiento del mundo" que se atribuyen los isleños como sociedad.

No es posible encontrar en el archipiélago relaciones de alteridad como la que existe entre los mucureros y los isleños, pues, por un lado, Tintipán es habitado por familias de isleños que se consideran nativos del Islote y no de Tintipán y cuya estadía en dicha isla no es permanente, $y$, por otro, la tercera isla de este grupo, Ceycén, aunque tiene una presencia permanente de dos familias de comerciantes de pescado, es percibida como una estación pesquera donde fluctúa la presencia cíclica de los pescadores que buscan acumular dinero en esta isla para luego volver al Islote.

\subsection{Ceycén: el "banco" de los pescadores}

Antes de cada temporada de fiesta (Virgen del Carmen, Cruz de Mayo, Navidad) ${ }^{32}$ diferentes pescadores isleños preparan su material para trasladarse temporalmente a Ceycén. Esta isla, que se encuentra a $8 \mathrm{~km}$ de distancia del Islote, está dividida en dos partes debido a la erosión causada por las mareas. Su costado este se encuentra ocupado por un empresario externo al archipiélago que instaló allí un hotel. En la otra mitad se extiende a lo largo de una playa blanca el caserío de los pescadores. Esta playa es ancha y generosa y sirve como espacio de reposo en las tardes, cuando los pescadores regresan de sus faenas y estacionan sus embarcaciones. Allí, cada atardecer, se agolpan los pelícanos que son llamados localmente longanos y se han acostumbrado a la presencia humana y consumen los peces que desechan los pescadores en el muelle principal.

En este mismo extremo, los isleños y algunas personas provenientes de lugares como Berrugas y Rincón han ido construyendo a lo largo del tiempo ranchos en madera y palma para habitar temporalmente. Así, antes de viajar a Ceycén, el pescador que no posee un rancho en dicha isla debe asegurarse un techo. Para esto, pide en préstamo o alquila uno de los ranchos existentes. Éstos cuentan con una o

\footnotetext{
${ }^{31}$ El mundo es una categoría que se relaciona con diferentes aspectos de la vida, como la viveza, la movilidad, la rapidez y el hecho de viajar. A los portadores de alguna de estas características se les dice que "tienen mucho mundo" o que "son muy mundanos". Se infiere que por esta razón, los isleños bautizaran como mundanos a los mapaches, pues son difíciles de atrapar y rápidos.

${ }^{32}$ Para tener más información sobre la influencia de las fiestas en los ciclos de pesca ver Heckadon (1970: 99-106).
} 
dos habitaciones y un patio trasero que se comunica con el monte de manglar. Generalmente carecen de camas y los pescadores llevan su propia hamaca, de tal manera que en algunos casos en una sola casa pueden acomodarse un grupo de tres o cuatro personas. En la mayoría de los casos, los pescadores que van a Ceycén viajan sin sus mujeres o son hombres solteros y jóvenes. Esta situación acentúa la solidaridad masculina en las labores que corresponden al espacio doméstico. Por ejemplo, la mayoría de pescadores que viven juntos temporalmente cocinan en conjunto cuando llegan de las faenas de pesca. Tal factor contribuye a economizar los gastos de los pescadores, pues el fin principal de vivir temporalmente en Ceycén es el ahorro de una cantidad suficiente de dinero que, además de las fiestas, está motivado por la necesidad de pagar deudas, por la escasez de pesca en los alrededores del Islote y por la influencia de las corrientes que cambian de acuerdo con el periodo ${ }^{33}$.

Hay varias razones por las cuales los pescadores escogen esta isla para dedicarse a la pesca; entre ellas está la cercanía de bajos, que son arrecifes que se encuentran a profundidades variables ${ }^{34}$. La otra razón, es la presencia de compradores de pescado que ofrecen mejores precios que en el Islote. Uno de ellos es un isleño que tiene el monopolio de la venta de pescado en esta isla. Él construyó su propia casa en cemento, así como la bodega donde almacena el pescado y los víveres que vende en una pequeña tienda que se encuentra en una de las habitaciones exteriores de su casa. Vive con su esposa, quien atiende a los pescadores mientras su esposo se encarga de recibir y almacenar el producto y de transportarlo a Tolú y Cartagena donde es vendido. Este comerciante, que es a la vez un pariente cercano de los isleños, controla la venta y consumo de bebidas alcohólicas en la isla, pues él mismo no vende alcohol para así impedir que los pescadores se distraigan en su trabajo. Asimismo, les facilita agua, pues ofrece el libre acceso a un depósito artificial.

A pesar de la dureza de las faenas que se viven cada mañana, los isleños conciben a Ceycén como un lugar donde también es posible alejarse del "bullicio" del Islote y descansar. No obstante, muchos se quejan por la necesidad de cocinar después de las fuertes faenas. Por esta razón, muchas mujeres isleñas y múcureras encuentran en esta isla una posibilidad de trabajo, pues van por temporadas a vender comidas para los pescadores o trabajar en el hotel aledaño al caserío de Ceycén donde son contratadas en la cocina.

\footnotetext{
${ }^{33}$ Las posibilidades y los tipos de pesca varían de acuerdo con las condiciones del agua y los vientos, por ejemplo, la época propicia para el buceo de langosta es el verano ya que se requieren aguas claras y corrientes débiles.

${ }^{34}$ En el Islote se pescan las especies marinas que habitan los bajos o arrecifes más que la pesca pelágica o de mar abierto (Heckadon, 1970). Así, podemos encontrar en el lenguaje del pescador isleño referencias a distintos bajos, como Las Picúas o Minalta, que los isleños conocen a la perfección y que son su medio de subsistencia.
} 
En Ceycén predomina la presencia isleña, pero pueden confluir sin problema personas de Múcura y de otras partes cercanas. No obstante, el hecho de que el monopolio de la compra de pescado esté en manos de un isleño que es miembro de una de las familias más extendidas de la isla, y que la propiedad de los terrenos ocupados por ranchos sea en la gran parte de isleños, hace que éstos conciban a Ceycén como una isla propia. Esto fue notorio para mí cuando acompañé a un grupo de isleños a seguir el culto evangélico en esta isla. Antes de iniciar el culto el pastor pidió que levantaran la mano "Todos los que son de aqui (Ceycén)" y la mayoría de personas levantó la mano, una mujer dijo: "¿Los que somos de aqui? ¡Todos somos! Esto pertenece al Islote", luego, el pastor corrigió "No, no, los que viven aqui" y levantaron la mano algunos pescadores isleños. Este evento muestra una dimensión de la territorialidad isleña. Ésta, además de extenderse con la apropiación para el cultivo y el trabajo turístico, se extiende con la implantación de estaciones de pesca. La pesca en este sentido, puede entenderse como una práctica performativa del espacio isleño. Pues las islas de Mangle y Panda, son concebidas como estaciones de pesca "propias" de los pescadores que vienen de otras poblaciones como Berrugas y Rincón. En este sentido, colonizar una isla para "arrancharse" y pescar, es una forma de producir un espacio anexo y predominantemente masculino.

Las características de cada isla revelan las diferentes formas de apropiación del territorio insular ${ }^{35}$. El Islote aparece como el eje del archipiélago y es, en cierta forma, una representación de "la idea urbana" re-significada interiormente que los isleños adquieren en sus contactos con otras poblaciones. Tintipán es la representación íntegra del "monte", es decir de la naturaleza. Múcura combina el turismo con un espacio "salvaje" que hace surgir formas de identidad entre dos poblaciones del archipiélago. Ceycén es el espacio colonizado por los pescadores y un importante proveedor económico. Sin embargo, como lo hemos dicho antes, lo que podemos entender como el espacio isleño se extiende más allá del conjunto de relaciones entre las islas que conforman el archipiélago. Los isleños también establecen relaciones espaciales con las poblaciones costeras con las que tienen relaciones históricas y que constituyen otra forma de espacialidad isleña.

\section{Redes espaciales externas del archipiélago}

En este aparte describiré el tipo de relaciones que los isleños mantienen con dos ciudades: Tolú y Cartagena. Aquí describiremos los procesos de movilidad hacia y

\footnotetext{
${ }^{35}$ Aunque aquí no analizamos el papel del mar como parte del espacio isleño por restricciones de espacio, reconocemos el papel esencial del mismo en la construcción de interacciones sociales y su espacialidad.
} 
desde el archipiélago, de los isleños pero también de otros actores como los turistas y los intermediarios turísticos. Estas interacciones nos muestran, como afirma Cailli (2009), que la espacialidad también se compone de los contactos, los trayectos cortos y largos y los intercambios y no pasa necesariamente por la apropiación de un territorio. No obstante, como veremos para el caso de la redes familiares, la movilidad isleña también ha promovido históricamente una cierta apropiación de terrenos en distintos barrios de Tolú y Cartagena.

\subsection{El turismo hacia el archipiélago de San Bernardo}

Según las narraciones de algunos isleños el turismo hacia el Archipiélago de San Bernardo comenzó hacia la década de 1970, cuando un grupo de hermanos isleños inició la venta de gaseosas y cervezas a los turistas que llegaban principalmente de Tolú hacia la playa La Punta. En esa población comenzó a desarrollarse poco a poco la industria turística, algunas familias comenzaron a comprar embarcaciones y a crear alrededor del puerto unos establecimientos llamados marinas.

Dichas marinas cumplen también la función de hoteles que albergan a precios cómodos a los turistas que llegan de ciudades como Medellín, Bogotá, Cali, entre otras poblaciones. Allí, proponen un trayecto por el Archipiélago de San Bernardo, que comienza en la "Punta norte" del Golfo de Morrosquillo y termina en la isla de Múcura donde los turistas pasarán el día. Este es un proceso que comienza todas las mañanas cuando los turistas interesados van a las marinas de Tolú —que se encuentran a lo largo de la playa - para embarcarse hacia el Archipiélago. Allí, juegan un papel esencial los lancheros o conductores de las embarcaciones. Ellos se encargan de acomodar a los turistas en las lanchas donde pueden llegar a caber hasta 15 personas.

La inserción de los isleños en el proceso turístico está relacionada con los lazos de parentesco y amistad que los vinculan con los lancheros; por ejemplo, uno de ellos es hijo de una de las mujeres de la isla. Esta situación les brinda la posibilidad a las personas del Islote de acceder a favores especiales como el transporte a menor costo o incluso gratuito de los miembros de la familia o de mercancías. Esta comunicación favorece la movilidad de los isleños hacia Tolú, así como el envío de pescado, dinero, ropa y mensajes a sus familiares en esta ciudad. Otros lancheros que no son familiares de isleños también tienen este rol comunicante, sin embargo, éste dependerá de un intercambio de servicios y dones en el que los isleños podrán ganar la confianza de los lancheros retribuyendo sus servicios con productos de pesca.

Los lancheros embarcan a las personas en el muelle de Tolú, entre el oleaje que mece las lanchas y el acoso de los vendedores ambulantes, recolectan el dinero del viaje o los boletos que indican que las personas han pagado y hacia las 9 de la mañana emprenden el trayecto. Éste es denominado "visita panorámica a las Islas 
de San Bernardo" y comienza en la isla Boquerón que es la primera en el recorrido que se realiza desde la punta norte del Golfo de Morrosquillo. Allí, entre la vista de las palmeras y cabañas en un costado de la isla y el manglar donde se posan las garzas blancas, el lanchero detiene su embarcación con ayuda de un acompañante y explica el recorrido que comenzará con una visita a Isla Palma donde existe un zoológico que antes pertenecía a un narcotraficante y ahora es administrado por el Estado. En la descripción sobre el recorrido el lanchero llama la atención de los turistas sobre el Islote y afirma que dentro de la visita panorámica ellos tendrán la oportunidad de ver "la isla más densamente poblada del mundo" 36 . Este toque exótico es alimentado en el discurso local con datos demográficos que el lanchero exagera diciendo que allí habita un total de 1.200 personas y que para acceder a una casa es necesario atravesar el interior de las mismas. No obstante, el Islote constituye sólo un lugar de paso en el trayecto, pero esta construcción de la imagen isleña a partir del discurso de los agentes turísticos se ha convertido en uno de los emblemas del recorrido desde Tolú.

En este recorrido es posible que se encuentren algunos pasajeros isleños que están acostumbrados a dicho discurso. No obstante, muchos son indiferentes a estas descripciones y lo toman como parte necesaria de la cotidianidad que se vive en el trayecto. Otros lo aprovechan para llamar la atención de los turistas en la playa $L a$ Punta y muchas veces logran conseguir un grupo interesado en ir a visitar el Islote, lo cual les genera un ingreso adicional. Internamente hay algunos que se quejan de la exageración de algunos lancheros sobre sus condiciones de vida, sin embargo este disgusto no pasa de ser solo una manifestación de inconformismo pasajero. En el recorrido, a veces las lanchas se detienen a tomar fotos desde las orillas del Islote y preguntar algunos aspectos de la vida de las personas. Los isleños, acostumbrados al paso de estas presencias pasajeras, continúan haciendo sus labores diarias sin prestar mayor atención a las miradas turísticas.

El lanchero sigue su camino hacia la playa de Múcura, La Punta, donde lo esperan ansiosos los restaurenteros, careteros, cocteleros, las vendedoras de dulces típicos. Ellos comienzan a ofrecer sus servicios y los lancheros se instalan en un rincón de la playa a esperar que pase el día para los turistas. En este momento entran en estrecha interacción con los dueños de restaurantes y con los otros trabajadores de la playa, entregan los mensajes, etc. Algunos, en el momento de partir se detienen en el Islote para recoger alguna mercancía (generalmente pescado) o persona que requiera de sus servicios para llegar a Tolú. Las madres que tienen algún familiar en esta ciudad envían con los lancheros a los niños ya sea por razones de estudio, familiares (visita a los parientes) o médicas. Así, de regreso a Tolú

\footnotetext{
${ }^{36}$ Esta afirmación no tiene asidero en estudios comparativos. No existe ninguna base para afirmar esto, sin embargo, con los años se ha convertido en el emblema del turismo hacia el Islote.
} 
estas dinámicas se esclarecen con la observación del puerto de llegada y desembarque de pasajeros. En este momento, es posible ver diferentes isleños o familiares de isleños que esperan las lanchas a sabiendas que hay algún mensaje, una mercancía o una persona que llega.

Existen, claro está, otras vías por las cuales llega el turismo al archipiélago y que alimentan las dinámicas de interacción con otras ciudades. Por ejemplo, el transporte de pasajeros entre Cartagena y el hotel de lujo en Múcura es también una posibilidad para los isleños que requieren viajar a dicha ciudad. No obstante, esta dinámica es más restringida, pues los turistas del hotel tienen prioridad y los isleños están obligados a pagar por el transporte. Si bien esta movilidad siempre ha existido, la frecuencia turística entre dicha población y el archipiélago, así como la creación de lazos entre los lancheros como agentes de la comunicación entre un lugar y otro, ubican a Tolú como uno de los ejes territoriales más importantes de los isleños.

\subsection{Redes familiares}

Como mostramos en la primera parte de éste trabajo, la historia del Islote comenzó con el desplazamiento periódico de distintos individuos que llegaron de Barú motivados por el cultivo del coco y la posibilidad de dedicarse a la caza de tortugas, que eran abundantes en esa época. Poco a poco, esta población creció con la llegada progresiva de las mujeres y los hijos de estas personas. A ellos se sumaron otros parientes. Posteriormente, llegaron individuos de otras partes, como Tolú, Cartagena, Rincón, Berrugas, así como otras poblaciones no costeras del Caribe. La mayor parte de éstos eran pescadores o comerciantes solitarios que llegaron navegando y por distintas razones (mejores posibilidades de pesca, consecución de pareja) se quedaron y se aliaron con mujeres isleñas, estableciendo nuevos grupos residenciales en la isla. El siguiente aparte, ofrecido por Maria Josefa Castillo, una de las mujeres mayores del Islote, muestra una manera de entender este proceso de poblamiento:

Ellos (sus abuelos) vinieron ya siendo unos adultos, porque eran pescadores y venían a pescar aquí; entonces esto era un cayo, no era una isla, así que ellos fueron unos de los primeros que llegaron aquí y después llegaron los otros. Llegaron a pescar en esta isla y después ya hicieron los ranchos [y en ese momento] fue que se devolvieron a Tolú y se trajeron a la familia (Comunicación personal, 9 de abril de 2010).

Casi todos los relatos en el Islote narran una primera instalación individual o en parejas, y la posterior búsqueda de los familiares en otras poblaciones. Estos mantuvieron el contacto con sus poblaciones de origen, donde tenían parientes consanguíneos y afines. Las redes se ampliaron también con la creación de vínculos poste- 
riores a la instalación gradual de los isleños a raíz de las oportunidades de trabajo que muchos isleños encontraron en otras poblaciones. Además del comercio del coco y la pesca, otras razones de la movilidad de los isleños fueron el contrabando de mercancía con Panamá que tuvo su auge a comienzos del siglo XX, el comercio de carbón que fabricaban los isleños y lo llevaban a Cartagena hasta que llegó a esta ciudad la luz eléctrica.

Por otro lado, muchos isleños emprendieron una búsqueda hacia otras poblaciones costeras para conocer parientes (padres, abuelos, hermanos, padres, tíos) de los cuales tuvieron referencia por conversaciones con sus parientes de la isla o por encuentros casuales que los motivaron a buscar a sus consanguíneos. Las genealogías recolectadas dan cuenta de distintas historias de encuentros en medio de fiestas $\mathrm{y}$ de otras situaciones informales en las que muchos isleños fueron descubriendo su relación con distintos parientes consanguíneos a lo largo de las poblaciones costeras. Esta red de lazos de parentesco se acentuó con la poligamia de diferentes hombres isleños que establecen relaciones y tienen descendencia con mujeres de otras poblaciones y regresaban a su hogar en el Islote. Aunque cada vez son menos pronunciadas, este tipo de relaciones marcaron la movilidad de los isleños entre distintos puntos territoriales que perdura en la actualidad. A estas relaciones, se suman los lazos de parentesco y las relaciones de compadrazgo, donde predomina la elección de compadres y comadres externas al Islote.

Así, lo que podemos entender como redes familiares en el Islote, es un grupo de relaciones entre distintos individuos que comparten lazos de consanguinidad, alianza, compadrazgo y que vinculan distintos puntos territoriales (Islote, Cartagena, Tolú, Barú) por medio de la movilidad constante de los hombres y mujeres isleñas. Estas redes, no solo son visibles en los desplazamientos de personas y el intercambio de mercancías o mensajes que acabamos de describir por medio del turismo. También en las temporadas de fiestas patronales cuando muchos isleños viajan solos o en grupo. Días antes de las mismas, se comunican o envían con los lancheros las razones de su llegada a sus parientes. Una vez allí, se establecen en barrios específicos donde es posible encontrarse fácilmente a un isleño en cada esquina en épocas de fiesta. Muchos isleños se refieren a estos lugares como "sus barrios" en Tolú o en Cartagena o su casa en Rincón, Berrugas o Libertad.

Por otro lado, estas redes también son perceptibles gracias la movilidad de los niños entre el Islote y Cartagena o Tolú. Ellos salen del Islote para continuar su crianza en otros lugares o viceversa. Allí son recibidos por sus parientes consanguíneos (madres, tías o tíos, primas, o sus compadres y comadres...) quienes se encargarán de ellos hasta que cuenten con una cierta independencia, ya sea por la finalización de la edad escolar o por el inicio de actividades económicas.

Hay dos formas de entender estas redes familiares en tanto que maneras de apropiación de territorios continentales y de interacción con otros espacios sociales. Una, es la propiedad de los isleños de dichas casas por la herencia que las primeras generaciones de isleños dejaron a sus hijos de terrenos o casas en Cartagena y/o 
Tolú, que dichos herederos conservaron como puntos para la acogida de familiares y amigos. Otra manera es por la construcción de nuevas viviendas por parte de los isleños con mujeres de estas ciudades o viceversa. Estas parejas crean un punto de estadía permanente a donde llegan constantemente sus parientes consanguíneos y afines del Islote; por ejemplo, la señora María tiene una casa que construyó con su esposo en Cartagena, pues éste heredó dicho terreno de sus padres, al quedar viuda quedó con la propiedad de dicha casa que sus hijos e hijas le ayudan a mantener. Actualmente, ella viaja constantemente Cartagena y allí viven permanentemente sus tres nietas con sus respectivos hijos. Ellas reciben a sus parientes (madre, hermano) que llegan del Islote a la que consideran también como "su casa" en Cartagena. Allí, la señora María es la cabeza principal de la familia aunque no resida permanentemente en dicha ciudad. Ella identifica esa casa como "suya" sin que esto implique que abandona la referencia y la identidad con "su isla". Allí, los isleños que viven permanentemente en el Islote se alojan por periodos que no tienen un patrón establecido. La duración depende de la razón de su viaje. Por ejemplo, si una persona tiene que resolver asuntos médicos, permanece en la ciudad - generalmente es Cartagena el punto de acceso a los servicios de salud- el tiempo que duren los trámites, las consultas o los exámenes. Durante este tiempo, sus parientes le asegurarán alojamiento y, dependiendo de su posición en la familia, la persona deberá responder con dinero o servicios. Es muy importante recalcar que Cartagena es el punto administrativo de los isleños. Allí acceden a trámites de ciudadanía y registro de nacimiento de los niños. En este sentido, las redes les otorgan la posibilidad de "existir" legalmente como ciudadanos colombianos, más allá de su situación como habitantes de un corregimiento insular.

La estadía prolongada en el Islote me permitió acoplarme gradualmente a estas redes. Así, a cada viaje hacia Tolú o Cartagena me era posible encontrar fácilmente un lugar de acogida en el hogar de algún isleño en estas poblaciones. También pude contribuir yo misma al transporte de mercancías, mensajes e incluso niños. Dichas trayectorias me permitieron reconocer que el vaivén entre un lugar y el otro contribuye no solo a la creación y la ampliación de estas redes familiares, sino también al intercambio de distintos elementos culturales y religiosos, que transforman y recomponen poco a poco la vida social de los isleños.

\subsection{La movilidad religiosa}

Hasta el año 2010 las prácticas religiosas en el Islote se encontraban diseminadas en las diferentes elecciones individuales, y la relación personal con los santos católicos y las fiestas patronales eran los puntos de reunión en torno a la figura religiosa. Esta situación es paralela a la que Losonczy describe para el caso de Dibulla (Guajira colombiana), donde "el itinerario ritual de un individuo aparece así como un vaivén periódico entre prácticas y figuras rituales de recursos cuya elección depende del 
momento" (2002: 14). Así, en la isla se pueden encontrar en algunas casas las imágenes de santos de devoción como José Gregorio Hernández ${ }^{37}$, también la Virgen del Carmen, patrona de los pescadores, ocupa un lugar importante en la iconografía religiosa de las familias isleñas. Por otro lado, se presentan esporádicamente curas católicos para realizar bautizos y matrimonios colectivos.

La presencia religiosa en la isla se identifica actualmente con la influencia evangélica, debido a la llegada de dos pastores que se quedaban por temporadas de dos a tres semanas ${ }^{38}$. En su ingreso jugó un papel fundamental una mujer isleña que habita en Tolú. Ella asistía a una de las Iglesias evangélicas y al conocerlos vio la necesidad de llevarlos a la isla, que consideró "necesitada de Cristo". Así, el Islote se fue convirtiendo en un eje de llegada de distintos pastores evangélicos. En el año 2011 se instaló definitivamente el Movimiento Misionero Mundial en la isla. Este ocupa actualmente un espacio que antes era destinado a la gallera.

La llegada constante de pastores religiosos tiene siempre un origen en las redes familiares existentes en Cartagena y Tolú. Esta influencia se fortalece con la circulación de material audiovisual que llega por la vía de comerciantes provenientes de otras poblaciones. Antes de la instalación definitiva de los pastores en la isla este material sirvió como sostén de las prácticas religiosas aisladas como las alabanzas personales o la referencia a pasajes de la biblia. Estas prácticas se reactivaban a la llegada de cada pastor.

\subsection{Circulación de objetos}

Todos estos intercambios generan en la isla la importación de significados, percepciones y productos que son resignificados internamente y le permiten a los isleños mantener la conexión, no solo material, sino cultural y social con sus vecinos continentales. Cada regreso a la isla implica la introducción de alguna novedad: bien sea una noticia, bien elementos como música, ropa o material audiovisual. En este proceso el referente principal del comercio cartagenero es el Mercado Bazurto que es un popular espacio comercial de Cartagena donde se combina la venta de todo tipo de enseres, como ropa, comida y electrodomésticos. Allí, los isleños aprovechan para comprar la ropa y música que darán a conocer a su regreso al Islote.

La relación Islote-continente se encuentra también ligada a la transformación de la vestimenta cotidiana de los isleños a una que es considerada como "la ropa bonita" (zapatos cerrados, pantalón largo, camisa de cuello, jeans). La preparación

\footnotetext{
${ }^{37}$ Médico venezolano abocado a la vida religiosa que se considera un santo en países como Colombia y Venezuela. No fue canonizado por la Iglesia.

${ }^{38}$ Una descripción detallada de esta incursión se puede encontrar en Leiva (2012).
} 
para viajar a alguno de los lugares de la costa Caribe o a ciudades principales de Colombia implica el porte de esta vestimenta, aspecto que en el Islote es visible para todos los habitantes. Esto es notorio cuando una persona que se desplaza en la isla portando "ropa bonita" es objeto de la mirada y de las expresiones de los isleños. Estos, cuando ven pasar a la persona con esa vestimenta le preguntan "¿Vas para Tolú?", expresión que es aceptada como un halago por quien la recibe. Aunque parece un detalle sin importancia esta expresión designa una de las representaciones que la "ciudad" tiene dentro de la isla. Así lo describe un isleño de 50 años que muestra "la manera de comportarse" en la ciudad con respecto al Islote: "Yo aqui [en el Islote] le puedo andar en chancleta ${ }^{39}$ todo el día pero en la ciudad me rasuro diario, tengo que ponerme buenos zapatos, buena gorrita pero en la ciudad no" (Comunicación personal, septiembre 2011). Así, además del ingreso de personas como turistas o pastores evangélicos, la representación de "lo urbano" pasa por el cuerpo y la forma de vestir que se presenta en la "salida" del Islote y el viaje a "la ciudad".

La circulación material conlleva también la importación de novedades musicales. Por ejemplo, la música champeta ${ }^{40}$, que es uno de los ritmos típicos de la región, ingresó a la isla por medio de grandes equipos de sonido llamados localmente picó $(\text { pick-up })^{41}$ que llevaban algunos visitantes, andariegos o comerciantes venidos de ciudades como Cartagena o poblaciones como Barú. Esa práctica continúa, hasta el punto en que hay jóvenes que construyen sus propios equipos y generan una competencia interna por quien es el mejor al imitar los eventos que se realizan entre distintos barrios de Cartagena. Los pasos de baile, tanto de esta música como de otros ritmos, también llegan por la vía de las personas (especialmente niños y adolescentes) que incursionan con nuevas tendencias a las que los isleños añaden variaciones locales como marca de estilo propio del baile en la isla.

Las dimensiones anteriores expresan el proceso de espacialidad isleña. Estos contactos les permiten resignificar sus relaciones internas; por ejemplo, por medio de la influencia de la religión y del turismo o en la transformación corporal. En la otra dirección, es decir, del Archipiélago hacia la zona continental colombiana, este vaivén influye en la apropiación de diferentes espacios, como barrios en Tolú o en Cartagena, donde los isleños van a ser figuras itinerantes. En estos lugares, los isleños movilizan la coexistencia de múltiples identidades. Es decir, un isleño al

\footnotetext{
${ }^{39}$ Calzado abierto y ligero usado en tiempo de calor.

${ }^{40}$ Música de origen africano inspirada especialmente en ritmos congoleses, la cual en el contexto del Caribe colombiano adquirió matices que la dividen en dos categorías: la champeta africana, y una champeta adaptada fonética e instrumentalmente llamada la "champeta criolla".

${ }^{41}$ Sistema de sonido formado por grandes amplificadores. Son ambulantes y en la costa Caribe colombiana tienen una estrecha relación con la identidad de los barrios populares. Llevan nombres particulares y decoraciones llamativas.
} 
llegar a Cartagena se identifica como cartagenero sin dejar de ser isleño o "costeño". Sin embargo, colectivamente, los isleños van a ser reconocidos como tales en el discurso de los habitantes de los barrios o en el de los lancheros, el de los turistas que se interesan por conocer el Islote, los comerciantes que circulan entre el archipiélago y otras poblaciones. El discurso general sobre los isleños, sobre todo en Tolú y en pequeñas poblaciones de la costa como Berrugas y Rincón, es el de personas receptivas, cordiales y generosas que "viven bien a pesar de sus condiciones estrechas".

\section{Conclusión}

El análisis de la apropiación territorial y la espacialidad isleña nos permite reconocer modelos de ordenamiento y uso del espacio que surgen al margen de los que son construidos desde el Estado. Estos procesos se deben entender en el contexto histórico nacional del proyecto decimonónico de construcción de Nación en Colombia. En este, las sociedades insulares y costeras fueron concebidas como territorios marginales y clandestinos. Como afirma García Chávez, en dicho proceso "predominó la perspectiva continental en la que la separación entre tierra y agua fue definitiva, alejando inevitablemente a las islas que perdieron su conectividad con el verdadero territorio" (2009: 15). Así, las sociedades insulares nunca fueron concebidas como espacios provistos de un ordenamiento espacial.

En el contexto estatal actual, el Islote está sometido a políticas que lo identifican como un corregimiento de Cartagena, es decir, lo convierten en una porción rural sometida a un espacio urbano. Asimismo, su ubicación dentro de un Área Marítima Protegida establece condicionantes a su población en tanto que habitantes de un espacio natural y sometido a las políticas de conservación. A estos dos marcos estatales se suman los procesos que conlleva la condición legal actual de su territorio. Pues desde el año 2011 los isleños emprendieron, con la ayuda de líderes locales y externos, una acción legal para ser declarados como "comunidad afrocolombiana". Esta situación ocurrió como respuesta a la necesidad de constituirse jurídicamente como un pueblo "ancestral" para acceder a la titulación colectiva del Islote, pues al ser una isla, éste es concebido por la legislación nacional como un terreno baldío perteneciente a la Nación. Es decir, la titulación colectiva, producto de las leyes promulgadas en la Constitución de 1991 y la Ley 70 de $1993^{42}$, les

\footnotetext{
${ }^{42}$ En 1993 se desarrolla el artículo transitorio 55 de la Constitución Nacional de Colombia de 1991 donde se reconoce el derecho de las comunidades negras que habitan en "zonas baldías, rurales y ribereñas" el derecho a la propiedad colectiva. Esta Ley se aplicó especialmente a las poblaciones ribereñas del Pacífico colombiano pero en los últimos años otras poblaciones han luchado por su aplicación en otras partes como el Caribe.
} 
aseguraría a los isleños el derecho a seguir habitando la isla como "comunidad". Así, a su interacción histórica con otros territorios donde los isleños pueden identificarse como costeños, isleños, tolueños y/o cartageneros, se suma la identidad coyuntural como "afrocolombianos", habitantes de un corregimiento y responsables de la conservación de su entorno natural. Los isleños ponen en escena estas identidades en contextos de diálogo con los funcionarios estatales.

Tal situación nos muestra la capacidad de los isleños de moverse en distintos espacios geográficos, normativos y sociales y son expresión de su configuración mestiza que "combina una referencia territorial común en constante fragmentación $\mathrm{y}$ una red de parentesco que reposa en afiliaciones diversas, en intersecciones geográficos culturales y sociales" (Losonczy, 2002: 25). Esta configuración mestiza expresa la confluencia de múltiples identidades que surgen en distintos escenarios del espacio isleño.

Otro de los escenarios recientes de la espacialidad isleña surge del acceso a internet, tanto por parte de los jóvenes isleños emigrados a la ciudad, como por parte de los propios isleños — aunque sea de forma limitada - en el Islote, lo que ha provocado que esta isla haya comenzado a aparecer en las redes sociales virtuales. Allí, los isleños expresan su arraigo a la isla, que describen como un lugar "ideal" provisto de convivencia, paz y solidaridad a pesar de su pequeñez y aislamiento. Estas imágenes son, en muchos casos, accesibles a otros internautas que no conocen el Islote. Estos reproducen sus impresiones sobre la isla por medio de foros que la muestran como "la isla más densamente poblada del mundo".

De esta forma, como lo muestra Massey (1991), la identidad no se limita a un territorio coherente y limitado. Al mismo tiempo, el hecho de habitar distintos espacios no desdibuja la especificidad del lugar. Pues la movilidad es en sí misma, un elemento constitutivo de un "sentido de lugar" que debe entenderse en la relación de ese lugar específico con otros (Massey, 1991: 9). En este caso, el ejemplo isleño nos muestra las distintas formas en que un espacio insular es habitado y habita en diferentes territorios, pues, por un lado, se prolonga más allá de las fronteras insulares formando un conjunto articulado de redes y territorios, y, por otro, en él confluyen distintas identidades que están inscritas en el cuerpo de sus habitantes y en sus diferentes formas de apropiación al territorio. Éstas se transforman en medio de la interacción con otras sociedades.

\section{Bibliografia}

Agnew, John (1994) “Territory”, en R. J. Johnston, D. Gregory y D. M. Smith (eds.) The Dictionary of Human Geography ( $3^{\mathrm{a}}$ ed. revisada y actualizada). Cambridge: Basil Blackwell, 620. 
Alonso, Oriana (2010) Una gran familia: humor e identidad en El Islote de San Bernardo, Cartagena, Bolivar. Tesis de pregrado. Bogotá: Universidad Externado de Colombia, Facultad de Ciencias Sociales y Humanas.

Cailly, Laurent (2009) "Des territorialités aux spatialités: pourquoi changer de sujet?", en M. Vanier (coord.) Territoires, territorialité, territorialisation. Controverses et perspectives. Rennes: Presses Universitaires, 151-156.

Congreso de la República de Colombia (2002) Ley 793 de 2002 por la cual se deroga la Ley 333 de 1996 y se establecen las reglas que gobiernan la extinción de dominio. Diario oficial, $\mathrm{n}^{\circ}$. 45.046.

DANE (Departamento Nacional de Estadística) (2005) Población Distrito de Cartagena de Indias (censo proyectado a 2010) [URL: <midas.cartagena.gov.co/Docs/CEnsoDane.xls>. Visitado el 13 de Octubre de 2012].

DANE (Departamento Nacional de Estadística) (s. f.) Conceptos Básicos [URL: $<$ http://www.dane.gov.co/files/inf_geo/4Ge_ConceptosBasicos.pdf $>$. Visitado el 13 de Octubre de 2012].

García Chávez, Catalina (2009) La territorialización del espacio marítimo en Colombia: una construcción de Nación a partir de los puertos del Caribe en el siglo XIX. Trabajo de grado presentado para optar al título de Magister en Historia. Bogotá: Universidad de Los Andes, Facultad de Ciencias Sociales, Departamento de Historia.

González, Gabriel (2003) Los nuevos pañamanes: Procesos identitarios y apropiación del espacio por el Continental Migrante Colombiano en la Isla de San Andrés, Caribe colombiano. Tesis de grado para optar al título de Antropólogo. Bogotá: Universidad Nacional de Colombia.

Guevara Natalia (2009) Redes isleñas, del archipiélago a la capital. Informe del proyecto de investigación "Del Archipiélago a la capital: recreación y reafirmación de la cultura e identidad raizal en Bogotá". Documento sin publicar.

Guevara, Natalia (2007) "San Andrés Isla: Memorias de la colombianización y reparaciones", en C. Mosquera Rosero-Labbé y L. C. Barcelos (eds.) AfroReparaciones, Memorias de la Esclavitud y Justicia Reparativa para negros, afrocolombianos y Raizales. Bogotá: Universidad Nacional de Colombia, 296304.

Guevara, Natalia (2005) Entre Colombia y el Caribe: el movimiento autonomista en San Andrés Isla. Trabajo de grado para optar al título de antropóloga. Bogotá: Facultad de Ciencias Humanas, Universidad Nacional de Colombia.

Heckadon, Stanley (1970) El Islote: estudio sobre el sistema económico de una comunidad de pescadores. Tesis de grado para optar al título de Antropólogo. Bogotá: Universidad de los Andes.

Herrera Angel, Martha (2002) Ordenar para controlar: ordenamiento espacial y control político en las Llanuras centrales de los Andes Neogranadinos, Siglo XVIII. Bogotá: Instituto Colombiano de Antropología e Historia.

Lefebvre, Henri (1991) [1974] La production de léspace. Paris: Éditions Anthropos. 
Leiva, Andrea (2012) “Cuando Cristo se «metió» al Islote: culto evangélico, atmósfera ritual e interacciones sociales en un territorio insular del Caribe colombiano". Revista Colombiana de Antropología, 48 (2), 39-66.

Leiva, Andrea (2004) "Man no sell yuh birthright, man les go fight": Dinámicas de reivindicación y autodefinición del Movimiento Raizal de San Andrés en medio de un escenario pluriétnico y multicultural. Tesis para optar al título de Magister en Antropología. Bogotá: Universidad de Los Andes, Departamento de Antropología.

Losonczy, Anne Marie (2002) "Marrons, colons, contrebandiers. Réseaux transversaux et configuration métisse sur la côte caraïbe colombienne (Dibulla)". Journal de la Société des Américanistes, 88, 179-201 [Puesto en línea el 5 de enero de 2007. URL: <http://jsa.revues.org/index2768.html>. Visitado el 23 de Julio de 2012].

Martínez, Claudia, y Uribe, Gonzalo (1975) Barú: un pueblo en la costa norte de Colombia, sus problemas y enseñanzas. Tesis para optar al título de antropólogos. Bogotá: Universidad de los Andes.

Massey, Doreen (1991) “A global sense of place”. Marxism Today, 35 (6), 24-29.

Rivera, Camila (2002) Old Providence: minoría no armonía. De la exclusión a la etnicidad. Tesis para optar al título de politólogo. Bogotá: Universidad de los Andes.

UAESPNN (2006) Plan de Manejo del Parque Nacional Natural Corales del Rosario y San Bernardo. Cartagena: Territorial Costa Caribe.

Valencia, Inge Helena (2011) "Impactos del reconocimiento multicultural en el archipiélago de San Andrés, Providencia y Santa Catalina: entre la etnización y el conflicto social". Revista Colombiana de Antropología, 47 (2), 69-95.

Valencia, Inge Helena (2002) El movimiento raizal: una aproximación a la identidad raizal a través de sus expresiones político-administrativas. Trabajo de Grado para optar al título de Antropóloga. Bogotá: Universidad Nacional de Colombia. 